OPEN ACCESS

Edited by:

Yuji Morita

Aichi Gakuin University, Japan

Reviewed by:

Rahman Md. Habiur,

Rajshahi University, Bangladesh Santi M. Mandal,

Vidyasagar University, India

Marc Habash,

University of Guelph, Canada

${ }^{*}$ Correspondence:

Renata K. T. Kobayashi

kobayashirkt@uel.br

Specialty section:

This article was submitted to

Antimicrobials, Resistance and

Chemotherapy,

a section of the journal

Frontiers in Microbiology

Received: 11 December 2015 Accepted: 05 May 2016 Published: 23 May 2016

Citation:

Scandorieiro S, Camargo LC Lancheros CAC, Yamada-Ogatta SF, Nakamura CV, Oliveira AG, Andrade

CGTJ, Duran N, Nakazato G and Kobayashi RKT (2016) Synergistic and Additive Effect of Oregano Essential Oil and Biological Silver Nanoparticles against Multidrug-Resistant Bacterial Strains. Front. Microbiol. 7:760. doi: 10.3389/fmicb.2016.00760

\section{Synergistic and Additive Effect of Oregano Essential Oil and Biological Silver Nanoparticles against Multidrug-Resistant Bacterial Strains}

\author{
Sara Scandorieiro ${ }^{1}$, Larissa C. de Camargo ${ }^{1}$, Cesar A. C. Lancheros ${ }^{2}$, \\ Sueli F. Yamada-Ogatta ${ }^{2}$, Celso V. Nakamura ${ }^{3}$, Admilton G. de Oliveira ${ }^{4}$, \\ Célia G. T. J. Andrade ${ }^{5}$, Nelson Duran ${ }^{6}$, Gerson Nakazato ${ }^{1}$ and Renata K. T. Kobayashi ${ }^{1 *}$ \\ 1 Laboratory of Basic and Applied Bacteriology, Department of Microbiology, Center of Biological Sciences, Universidade \\ Estadual de Londrina, Londrina, Brazil, ${ }^{2}$ Laboratory of Molecular Biology of Microorganisms, Department of Microbiology, \\ Center of Biological Sciences, Universidade Estadual de Londrina, Londrina, Brazil, ${ }^{3}$ Laboratory of Technological Innovation \\ in Drug and Cosmetics Development, Department of Basic Health Sciences, Center of Health Sciences, Universidade \\ Estadual de Maringá, Maringá, Brazil, ${ }^{4}$ Laboratory of Microbial Ecology, Department of Microbiology, Center of Biological \\ Sciences, Universidade Estadual de Londrina, Londrina, Brazil, ${ }^{5}$ Laboratory of Electron Microscopy and Microanalysis, \\ Department of General Biology, Center of Biological Sciences, Universidade Estadual de Londrina, Londrina, Brazil, ${ }^{6}$ Institute \\ of Chemistry, Universidade Estadual de Campinas, Campinas, Brazil
}

Bacterial resistance to conventional antibiotics has become a clinical and public health problem, making therapeutic decisions more challenging. Plant compounds and nanodrugs have been proposed as potential antimicrobial alternatives. Studies have shown that oregano (Origanum vulgare) essential oil (OEO) and silver nanoparticles have potent antibacterial activity, also against multidrug-resistant strains; however, the strong organoleptic characteristics of OEO and the development of resistance to these metal nanoparticles can limit their use. This study evaluated the antibacterial effect of a two-drug combination of biologically synthesized silver nanoparticles (bio-AgNP), produced by Fusarium oxysporum, and OEO against Gram-positive and Gram-negative bacteria, including multidrug-resistant strains. OEO and bio-AgNP showed bactericidal effects against all 17 strains tested, with minimal inhibitory concentrations (MIC) ranging from 0.298 to $1.193 \mathrm{mg} / \mathrm{mL}$ and 62.5 to $250 \mu \mathrm{M}$, respectively. Time-kill curves indicated that OEO acted rapidly (within $10 \mathrm{~min}$ ), while the metallic nanoparticles took $4 \mathrm{~h}$ to kill Gram-negative bacteria and $24 \mathrm{~h}$ to kill Gram-positive bacteria. The combination of the two compounds resulted in a synergistic or additive effect, reducing their $\mathrm{MIC}$ values and reducing the time of action compared to bio-AgNP used alone, i.e., 20 min for Gram-negative bacteria and 7 h for Gram-positive bacteria. Scanning electron microscopy (SEM) revealed similar morphological alterations in Staphylococcus aureus (non-methicillin-resistant S. aureus, non-MRSA) cells exposed to three different treatments (OEO, bio-AgNP and combination of the two), which appeared cell surface blebbing. Individual and combined treatments showed reduction in cell density and decrease in exopolysaccharide matrix compared to untreated bacterial cells. It indicated that this composition have an antimicrobial activity against $\mathrm{S}$. aureus by disrupting cells. Both compounds showed very low hemolytic activity, especially at MIC levels. This study 
describes for the first time the synergistic and additive interaction between OEO and bio-AgNP produced by F. oxysporum against multidrug-resistant bacteria, such as MRSA, and $\beta$-lactamase- and carbapenemase-producing Escherichia coli and Acinetobacter baumannii strains. These results indicated that this combination can be an alternative in the control of infections with few or no treatment options.

Keywords: oregano oil, biological silver nanoparticles, multidrug-resistant bacteria, synergism, antibacterial

\section{INTRODUCTION}

Bacterial antimicrobial resistance to most conventional antibiotics has become a clinical and public health problem. Infections due to multidrug-resistant microorganisms, such as bacteria that produce extended-spectrum $\beta$-lactamases (ESBL) and carbapenemases (Klebsiella pneumoniae carbapenemase, KPC) and MRSA can be challenging to control leading to high treatment costs, therapeutic failure and death (Silva and Lincopan, 2012; Cantas et al., 2013).

ESBL and KPC hydrolyze the $\beta$-lactam ring resulting in an inactive antimicrobial (Queenan and Bush, 2007; Drawz and Bonomo, 2010). ESBLs mediate resistance to most $\beta$ lactams, mainly in Gram-negative bacteria (Dhillon and Clark, 2012; Silva and Lincopan, 2012). In these cases, carbapenem antibiotics, such as imipenem, meropenem, and ertapenem, are drugs of choice for treatment. However, carbapenemases reduce treatment options because they inactivate penicillins, cephalosporins, monobactams, and carbapenems (Queenan and Bush, 2007).

Usually ESBLs and KPC are encoded by genes carried by mobile genetic elements which also carry resistance genes to other antimicrobial agents, contributing to the emergence of multidrug resistance and its rapid spread between different strains and species (Pitout, 2012; Silva and Lincopan, 2012; Patel and Bonomo, 2013; Shaikh et al., 2015). ESBL- and KPC-producing strains usually exhibit resistance to quinolones, tetracyclines, cotrimoxazol, trimethoprim, and aminoglycosides (Dhillon and Clark, 2012; Pitout, 2012; Patel and Bonomo, 2013).

In Gram-positive bacteria, the most common mechanism of resistance to $\beta$-lactam occurs due a mutant transpeptidase gene. Methicillin resistance in $S$. aureus occurs because of the mecA gene, which encodes transpeptidases that have low affinity for $\beta$-lactam antibiotics (Rice, 2012). MRSA strains can harbor resistance genes for other antimicrobials besides mecA, reducing treatment options (Turlej et al., 2011).

Multiresistant bacteria have been found in foods for human consumption, streams and effluents and thus it is a hospital, community, and environmental problem (Prado et al., 2007; Fontes et al., 2011; Silva and Lincopan, 2012; Rubin et al., 2014; Koga et al., 2015). As soon as new $\beta$-lactams are widely used, new $\beta$-lactamases are also discovered (Bush, 2010; Kong et al., 2010; Shaikh et al., 2015). Therefore, there is crucial need for research and development of new drugs

Abbreviations: OEO, oregano essential. oil; bio-AgNP, biological synthesized silver nanoparticle; RBC, red blood cells. with potential to combat resistant strains to minimize their selection.

Compounds from natural sources such as animals, plants, and microorganisms have been proposed as potential antimicrobial alternatives (Mandal and Mandal, 2011; Cardozo et al., 2013; Biasi-Garbin et al., 2015). Spice essential oils have been documented as being antimicrobial (Burt, 2004; Du et al., 2009; Betancourt et al., 2012; Nazzaro et al., 2013). Oil phenolic substances are mainly responsible for antibiotic properties (Rhayour et al., 2003; Burt, 2004; Nostro et al., 2007; Hyldgaard et al., 2012).

Studies on the antibacterial mechanisms of action of plant essential oils, including the OEO, suggest that hydrophobic bioactive compounds cause damage to cell membrane, increase cell permeability, affect ATP production, act on protein synthesis, cause cellular $\mathrm{pH}$ disturbance, induce cytoplasmic changes and interfere with quorum sensing (Helander et al., 1998; Ultee et al., 1999; Lambert et al., 2001; Rhayour et al., 2003; Souza et al., 2010, 2013; Szabó et al., 2010; Hyldgaard et al., 2012).

OEO, extracted mainly from the leaves of the herb $O$. vulgare by ecofriendly methods, has been reported as having broad antibacterial activity (Burt, 2004; Busatta et al., 2007; Betancourt et al., 2012). Other biological activities such as antifungal, antiviral, antioxidant and anticancer have been described for OEO (Cervato et al., 2000; Kalemba and Kunicka, 2003; Hyldgaard et al., 2012; Gautam et al., 2014; Gilling et al., 2014; Sobral et al., 2014).

Carvacrol and thymol are the main components of OEO (Nostro et al., 2004; Cleff et al., 2008; Hyldgaard et al., 2012; Stojković et al., 2013), and the antimicrobial activity of this oil varies according to their amounts. Synergistic and additive interactions between carvacrol and thymol have been reported (Bassolé and Juliani, 2012; Hyldgaard et al., 2012); furthermore, a mixture of compounds with antimicrobial activity could minimize the selection of resistant strains. Studies have shown that OEO has the potential to prevent food from being contaminated and control worrisome hospital infections (Nostro et al., 2004; Si et al., 2008; Barros et al., 2009; Amrouni et al., 2014; Honório et al., 2015). Despite the potential antimicrobial activity of OEO, its strong taste and smell seem to limit its use, so alternatives are needed to minimize or eliminate such undesirable characteristics (Burt, 2004; Alvarez et al., 2014).

Silver has been used for millennia to treat wounds and eye infections and to preserve food and water (Alexander, 2009). Nanotechnology has proved to be a useful tool for solving biomedical problems. Silver nanoparticles have been intensively studied as antimicrobial agents, including their use against 
multidrug-resistant bacteria ( $\mathrm{Li}$ et al., 2010; Cardozo et al., 2013; Naqvi et al., 2013; Ansari et al., 2014; Bibbs et al., 2014; Palanisamy et al., 2014; Singh et al., 2014; Subashini et al., 2014; Theophel et al., 2014). Through nanotechnology, it has been possible to revive the use of silver to combat resistant bacteria. Nanoscale enhances the antibacterial activity of silver even at low concentrations; nanometer metallic particles show altered physical, chemical and biological properties compared to conventional silver, due to their high surface-to-volume ratio (Nowack et al., 2011; Rai et al., 2012; Herman and Herman, 2014). Furthermore, silver nanoparticles have been reported to be less toxic than silver ions to host (de Lima et al., 2012).

The bactericidal mechanism of silver nanoparticles is not clearly understood; however, it is believed that there is a multiple mechanism of action (Herman and Herman, 2014). Researchers have suggested that silver nanoparticles cause cell membrane disintegration and increase cell surface permeability, inactivate bacterial enzymes by interaction with thiol groups, deplete levels of intracellular ATP, cause DNA damage and induce free radical formation (Feng et al., 2000; Dibrov et al., 2002; Lok et al., 2006; Li et al., 2010; Kim et al., 2011; Theophel et al., 2014).

Although silver nanoparticles show excellent antimicrobial activity, silver-resistant bacteria have been described; and these microorganisms can quickly develop resistance to silver nanoparticles by genetic alterations (Losasso et al., 2014; Graves et al., 2015).

The combination of several antimicrobials seems to be the best strategy for controlling emergence of antibiotic-resistant microorganisms (Fischbach, 2011; Bass et al., 2015; Bollenbach, 2015). Many studies show additive or synergistic antibacterial effects of silver nanoparticles combined with alternative (eugenol, phenazine-1-carboxamide, and cinnamaldehyde) and conventional (ampicillin, kanamycin, erythromycin, chloramphenicol, amoxicillin, ciprofloxacin, and moxifloxacin; Li et al., 2005; Fayaz et al., 2010; Cardozo et al., 2013; Ghosh et al., 2013; Theophel et al., 2014; Biasi-Garbin et al., 2015) antimicrobial compounds. Synergistic and additive antimicrobial effects have been reported for OEO or its components combined with eugenol, linalool, menthol, cinnamaldehyde, Thymus vulgaris essential oil, Rosmarinus officinalis essential oil, gentamicin, polymyxin, kanamycin, levofloxacin or many others (Rosato et al., 2007; Si et al., 2008; de Souza et al., 2009; Bassolé and Juliani, 2012; Stojković et al., 2013; Honório et al., 2015).

Biological systems have been extensively used for rapid and eco-friendly biosynthesis of silver nanoparticles; instead of using chemical reagents, these processes involve fungi, bacteria, plants and other organisms or biomolecules (Sastry et al., 2003; Durán et al., 2005, 2011; Sankar et al., 2013; Singh et al., 2014). This study evaluated, for the first time, the antibacterial effect of a two-drug combination composed of bio-AgNP synthesized by F. oxysporum and OEO against standard and resistant Grampositive and Gram-negative strains.

\section{MATERIALS AND METHODS}

\section{Bacterial Strains}

All antimicrobial assays were performed against reference strains from American Type Culture Collection (ATCC) provided by the Laboratory of Basic and Applied Bacteriology of Londrina Stated University (Londrina, Paraná, Brazil), and clinical strains provided from Londrina University Hospital (Londrina, Paraná, Brazil). The standard bacterial strains used were as follows: methicillin-sensitive S. aureus (ATCC 25923), Streptococcus mutans (ATCC 25175), E. coli (ATCC 25922), K. pneumoniae (ATCC 10031), K. pneumoniae (ATCC 700603), Salmonella enterica serovar Enteritidis (ATCC 13076), S. enterica serovar Typhimurium UK-1 (ATCC 68169) and MRSA N315 provided by Dr. Elza Masae Mamizuka (São Paulo University, São Paulo - SP, Brazil). Several clinical isolates obtained from Londrina University Hospital were also tested (Table 1). Four isolates of ESBL-producing E. coli and two isolates of carbapenemaseproducing E. coli from urinary tract infections (provided by Dr. Eliana Carolina Vespero, Londrina University Hospital, Londrina); one isolate of carbapenem-resistant A. baumannii from inguinal-rectal swabs (provided by Dr. Floristher Elaine Carrara Marroni, Londrina Clinics Hospital, Londrina) and two isolates of MRSA strains from secretions-general discharges (provided by Dr. Marcia Regina Eches Perugini, Londrina University Hospital, Londrina). The bacterial strains were stored in $25 \%$ glycerol (Merck) at $-80^{\circ} \mathrm{C}$.

\section{Antimicrobial Agents Oregano Essential Oil}

OEO was obtained from Ferquima Industry and Commerce of Essential Oils (São Paulo, Brazil). This oil (batch 224) was extracted by steam distillation and its density $(0.954 \mathrm{~g} / \mathrm{mL})$ and composition (main components: $71 \%$ carvacrol, $3 \%$ thymol, $4.5 \%$ gamma terpinene, $3.5 \%$ para-cymene, and $4 \%$ betacaryophyllene) were described in a technical report. A stock solution of 50\% OEO was prepared in dimethylsulfoxide (DMSO, Sigma-Aldrich; v/v). DMSO maximum concentration in assays was $1 \%$.

\section{Silver Nanoparticles}

Bio-AgNP were prepared according to a previously established method (Durán et al., 2005, 2006). This method of production has been patented (Patent, 2006, PI 0605681-4A2; http://www. inpi.gov.br). Briefly, bio-AgNP were obtained after reduction of silver nitrate by $F$. oxysporum, strain 551, from the culture collection of the Molecular Genetics Laboratory of ESALQ-USP (Piracicaba, São Paulo, Brazil). F. oxysporum was cultivated on media containing $0.5 \%(\mathrm{w} / \mathrm{v})$ yeast extract (Neogen), $2 \%(\mathrm{w} / \mathrm{v})$ malt extract (Neogen), 2\% (w/v) agar (Neogen) and distilled water at $28^{\circ} \mathrm{C}$ for 7 days. After growth, the fungal biomass was added to distilled water at $0.1 \mathrm{~g} / \mathrm{mL}$ and incubated at $28^{\circ} \mathrm{C}$ for $72 \mathrm{~h}$. Afterwards, the solution components were separated by filtration. $\mathrm{AgNO}_{3}$ (Nuclear) at $1 \mathrm{mM}$ was added to fungal-free solution, and the system was incubated for several hours at $28^{\circ} \mathrm{C}$ in the absence of light. Periodically, aliquots of the solution system were removed and absorptions were measured using an ultraviolet-visible spectrophotometry (Varian Cary 50 Probe); the peak at $440 \mathrm{~nm}$ corresponded to the surface plasmon resonance of silver nanoparticles. After bio-AgNP purification, diameter was determined by photon correlation spectroscopy using ZetaSizer NanoZS (Malvern), and zeta potential measurement was performed using the same instrument. 
TABLE 1 | Susceptibility to antibiotics of clinical strains.

\begin{tabular}{|c|c|c|c|c|c|c|c|c|c|c|c|c|c|c|c|c|c|}
\hline \multicolumn{7}{|l|}{ S. aureus } & \multirow{2}{*}{$\begin{array}{l}\text { PEN } \\
R\end{array}$} & \multirow{2}{*}{$\begin{array}{l}\text { OXA } \\
R\end{array}$} & \multirow{2}{*}{$\begin{array}{l}\text { CIP } \\
R\end{array}$} & \multirow{2}{*}{$\begin{array}{l}\text { RIF } \\
S\end{array}$} & \multirow{2}{*}{$\begin{array}{l}\text { GEN } \\
S\end{array}$} & \multirow{2}{*}{$\begin{array}{l}\text { STR } \\
\text { S }\end{array}$} & \multirow{2}{*}{$\begin{array}{l}\text { TET } \\
S\end{array}$} & \multirow{2}{*}{$\begin{array}{l}\text { ERY } \\
R\end{array}$} & \multirow{2}{*}{$\begin{array}{l}\text { CLI } \\
\mathrm{R}\end{array}$} & \multirow{2}{*}{$\begin{array}{l}\text { LNZ } \\
\mathrm{S}\end{array}$} & \multirow{2}{*}{$\frac{\text { SXT }}{S}$} \\
\hline MRSA 101 & & & & & & & & & & & & & & & & & \\
\hline MRSA 107 & & & & & & & $\mathrm{R}$ & $\mathrm{R}$ & $\mathrm{R}$ & S & $\mathrm{R}$ & $\mathrm{R}$ & S & $\mathrm{R}$ & $\mathrm{R}$ & $S$ & $\mathrm{R}$ \\
\hline E. coli & PTZ & CEP & CFZ & CTX & CAZ & CPM & AZT & IPM & MRP & ERT & NOR & CIP & LVX & GEN & AMI & SXT & NIT \\
\hline ESBL 167 & S & - & $\mathrm{R}$ & $\mathrm{R}$ & $\mathrm{R}$ & $\mathrm{R}$ & $\mathrm{R}$ & S & S & S & - & $\mathrm{R}$ & $\mathrm{R}$ & S & S & $\mathrm{R}$ & S \\
\hline ESBL 176 & S & $\mathrm{R}$ & - & $\mathrm{R}$ & $\mathrm{R}$ & $\mathrm{R}$ & 1 & $S$ & $S$ & S & - & $S$ & S & S & S & $S$ & S \\
\hline ESBL 192 & $S$ & S & - & $\mathrm{R}$ & $\mathrm{R}$ & I & $S$ & - & $S$ & $S$ & - & $\mathrm{R}$ & $\mathrm{R}$ & $S$ & S & $S$ & S \\
\hline KPC 131 & $\mathrm{R}$ & - & - & $\mathrm{R}$ & $S$ & S & $\mathrm{R}$ & $\mathrm{R}$ & $\mathrm{R}$ & $\mathrm{R}$ & - & $\mathrm{R}$ & - & - & S & - & - \\
\hline KPC 133 & 1 & - & - & $\mathrm{R}$ & 1 & 1 & $\mathrm{R}$ & $S$ & $\mathrm{R}$ & $\mathrm{R}$ & - & $\mathrm{R}$ & - & - & S & - & - \\
\hline \multicolumn{3}{|c|}{ A. baumannii } & PTZ & AMS & СTX & CAZ & CPM & $A Z T$ & IPM & MRP & ERT & CIP & LVX & GEN & AMI & TET & SXT \\
\hline
\end{tabular}

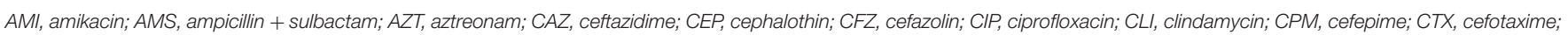

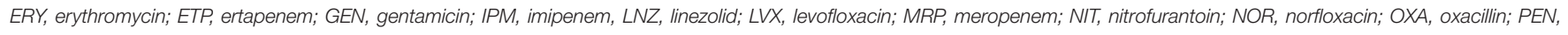
penicillin; PTZ, piperacillin + tazobactam; RIF, rifampin; STR, streptomycin; SXT, trimethoprim + sulfamethoxazole; TET, tetracycline.

$R$, resistant; S, susceptible; I, intermediate; (-), not tested.

MRSA, methicillin-resistant S. aureus.

ESBL, extended-spectrum beta-lactamases; KPC, K. pneumoniae carbapenemase; RC, carbapenem-resistant.

101, 107, 167, 169, 176,192, 131, 133, and 01 are strain numbers at Laboratory of Basic and Applied Bacteriology-Universidade Estadual de Londrina.

\section{Antibacterial Activity of OEO and Bio-AgNP Separately}

MIC was determined by the broth dilution method according to Clinical and Laboratory Standards Institute guidelines (CLSI, 2012), with necessary modifications. Tested concentrations of OEO and bio-AgNP ranged from 0.075 to $9.540 \mathrm{mg} / \mathrm{mL}$ and 1.91 to $500 \mu \mathrm{M}$, respectively. Mueller-Hinton broth (MHB, Difco) alone, MHB plus OEO and MHB plus bio-AgNP were tested as sterility controls, and untreated bacteria inoculated on MHB alone and with $1 \%$ DMSO were tested as growth control. After $24 \mathrm{~h}$ incubation at $37^{\circ} \mathrm{C}$, MIC was defined as the lowest concentration of antimicrobial agent that inhibited visible growth. Minimal bactericidal concentration (MBC) was determined by subculturing $10 \mu \mathrm{L}$ from the broth dilution MIC, after $24 \mathrm{~h}$ of treatment, in Mueller-Hinton agar (MHA, Oxoid) with no antimicrobial agent. MBC was defined as the lowest concentration that kills $\geq 99.9 \%$ of bacteria after $24 \mathrm{~h}$ of antimicrobial treatment (NCCLS, 1999). All assays were carried out in triplicate, and at least on three different occasions.

\section{Antibacterial Combination Assay}

Interaction of OEO and bio-AgNP was determined by broth dilution in double-antimicrobial gradient as described by Traub and Kleber (1975), with modifications. Single colonies of bacterial cultures grown in MHA media were suspended in saline solution ( $0.9 \%$ sodium chloride, w/v, Merck) and adjusted to 0.5 McFarland suspension which corresponds to $1 \times 10^{8}$ colonyforming units $/ \mathrm{mL}(\mathrm{CFU} / \mathrm{mL})$. The inoculum at $1 \times 10^{8} \mathrm{CFU} / \mathrm{mL}$ was diluted 1:100 in MHB to yield $10^{6} \mathrm{CFU} / \mathrm{mL}$. A volume of 0.05 $\mathrm{mL}$ of bacterial inoculum at $10^{6} \mathrm{CFU} / \mathrm{mL}$ was added to $0.05 \mathrm{~mL}$ of MHB complemented with combination of OEO and bio-AgNP whose concentrations ranged from 0.037 to $0.596 \mathrm{mg} / \mathrm{mL}$ and from 7.81 to $125 \mu \mathrm{M}$, respectively. Finally bacteria at $5 \times 10^{5}$ $\mathrm{CFU} / \mathrm{mL}$ were grown in MHB with both antimicrobial agents in combination at $37^{\circ} \mathrm{C}$ for $24 \mathrm{~h}$. Sterility and growth controls were performed as in the MIC determination assay described above. The interaction of both compounds was analyzed by fractional inhibitory concentrations index (FICI) according Chin et al. (1997), using the following equation: $\mathrm{FICI}=\mathrm{FIC}_{\mathrm{OEO}}+$ $\mathrm{FIC}_{\text {bio-AgNP }}$, where $\mathrm{FIC}=\mathrm{MIC}_{\text {combination }} / \mathrm{MIC}_{\text {individual }}$. FICI is interpreted as "synergistic" when $\leq 0.5$, as "additive" when $>0.5$ and $\leq 1$, as "indifferent" (no interaction) when $>1$ and $<4$ and as "antagonist" when $\geq 4$. All assays were carried out in triplicate, at least on three different occasions and against Gram-positive and Gram-negative bacteria, including multidrug-resistant strains.

\section{Time-Kill Assay}

Time-kill assay was carried out using the viable cells count method, according to NCCLS (1999), with modifications. Three conditions of treatments were tested, bacterial cultures treated with OEO, bio-AgNP and their combination; and a bacterial culture without antimicrobial agent served as growth control. At ten time points $(0 \mathrm{~h}, 30 \mathrm{~s}, 10 \mathrm{~min}, 20 \mathrm{~min}, 30 \mathrm{~min}, 2 \mathrm{~h}, 4 \mathrm{~h}$, $7 \mathrm{~h}, 10 \mathrm{~h}$, and $24 \mathrm{~h}$ ) of incubation at $37^{\circ} \mathrm{C}, 10 \mu \mathrm{L}$ from serial dilutions of treated and untreated cultures were transferred to MHA and CFU/mL were determined. All assays were carried out in triplicate, and at least on two different occasions, with three bacterial strains (S. aureus ATCC 25923, E. coli ATCC 25922 and carbapenemase-producing E. coli 131).

\section{Scanning Electron Microscopy}

S. aureus (ATCC 25923, non-MRSA) at $10^{9} \mathrm{CFU} / \mathrm{mL}$ were prepared in MHB and added to five tubes $(5 \mathrm{~mL}$ of bacterial inoculum each). S. aureus was exposed to three different 
treatments; OEO at $0.594 \mathrm{mg} / \mathrm{mL}$ was added to the first tube, bio-AgNP at $250 \mu \mathrm{M}$ were added to the second tube and the two compounds combined were added to the third tube (OEO at $0.297 \mathrm{mg} / \mathrm{mL}$ and bio-AgNP at $125 \mu \mathrm{M}, 2 \mathrm{x}$ synergistic MIC values to account for the increased cell density used for SEM analyses). Incubation times at $37^{\circ} \mathrm{C}$ varied for each treatment, $30 \mathrm{~min}$ for OEO and $6 \mathrm{~h}$ for bio-AgNP and combination of antimicrobials. Two untreated controls were prepared, one with $30 \mathrm{~min}$ incubation and another with $6 \mathrm{~h}$. After incubation, 20 $\mu \mathrm{L}$ of each sample were spotted onto poly-L-lysine (SigmaAldrich)-coated glass slides. Each slide containing treated or untreated bacteria was fixed (for $20 \mathrm{~h}$ ) by immersion in 1 $\mathrm{mL}$ of $0.1 \mathrm{M}$ sodium cacodylate buffer ( $\mathrm{pH}$ 7.2) containing $2.5 \%$ glutaraldehyde and $2 \%$ paraformaldehyde. All samples were then post-fixed in $1 \%$ osmium tetroxide for $2 \mathrm{~h}$. All reagents for both chemical fixations were provided from Electron Microscopy Sciences. Post-fixed cells were dehydrated in an ethanol gradient (Sigma-Aldrich) (70, 80, 90 and $\left.100^{\circ} \mathrm{GL}\right)$, critical point-dried using $\mathrm{CO}_{2}$ (BALTEC CPD 030 Critical Point Dryer), coated with gold (BALTEC SDC 050 Sputter Coater) and observed under a scanning electron microscope (FEI Quanta 200).

\section{Cytotoxicity Assay with Human Red Blood Cells (RBC) and HEp-2cells}

Hemolytic activity of OEO and bio-AgNP was determined according to Izumi et al. (2012), with necessary modifications. Blood was collected in heparinized tubes (Vacutainer) from a healthy human donor with voluntary consent, which was approved by the human ethics committee (CAAE 47661115.0.0000.5231, No. 1.268.019 - UEL). Erythrocytes were separated by centrifugation $\left(5000 \mathrm{rpm}, 4^{\circ} \mathrm{C}, 5 \mathrm{~min}\right)$ and were prepared in phosphate-buffered saline (0.1 M PBS, $\mathrm{pH} 7.2$ ) at $6 \%(\mathrm{v} / \mathrm{v})$. PBS was composed of $0.9 \%(\mathrm{w} / \mathrm{v})$ sodium chloride (Merck), 0.2 M monobasic sodium phosphate (Chemco) and 0.2 $\mathrm{M}$ dibasic sodium phosphate (Nuclear). In 96-well plates, 100 $\mu \mathrm{L}$ of $\mathrm{RBC}$ at $6 \%$ were added to $100 \mu \mathrm{L}$ of PBS with different concentrations of compounds individually and in combination. After $3 \mathrm{~h}$ of incubation at $37^{\circ} \mathrm{C}$, supernatants were read at 550 $\mathrm{nm}$ to monitor release of hemoglobin. Triton X-100 (SigmaAldrich) at $1 \%$ was used as control for $100 \%$ hemolytic activity, and hemolysis percentage was calculated for each compound concentration.

Cytotoxicity to the human laryngeal epithelial carcinoma cell line HEp-2 was performed by the colorimetric dimethylthiazol diphenyl tetrazolium bromide (MTT, Sigma-Aldrich) assay in 96well plates, according to the manufacturer's recommendations. HEp-2 cells were grown in RPMI medium 1640 (Gibco) at $37^{\circ} \mathrm{C}$ in $5 \% \mathrm{CO}_{2}$ to form a monolayer. Non-adherent cells were removed using PBS and confluent cells were treated with different concentrations of compounds individually and in combination for $24 \mathrm{~h}$ at $37^{\circ} \mathrm{C}$ in $5 \% \mathrm{CO}_{2}$. After incubation, the medium was removed and each well was washed with PBS. MTT solution (10 $\mu \mathrm{L}$ per well at $1.250 \mathrm{~g} / \mathrm{mL}$ ) was added to all wells, and plates were incubated at $37^{\circ} \mathrm{C}$ for $2 \mathrm{~h}$. MTT solubilization solution (SigmaAldrich) containing 10\% Triton X-100 in acidic isopropanol (0.1
$\mathrm{N} \mathrm{HCl})$ was added to each well $(90 \mu \mathrm{L}$ per well) to dissolve the dark blue crystals (formazan). After 15 min homogenization, the plate was read at $570 \mathrm{~nm}$. Untreated HEp-2 cells were used as control for $100 \%$ viability, and viability percentage was calculated for each compound concentration.

In both cytotoxicity assays, the concentrations of OEO and bio-AgNP ranged $0.037-9.540 \mathrm{mg} / \mathrm{mL}$ and $1.95-250 \mu \mathrm{M}$, respectively. The $50 \%$ cytotoxic concentration $\left(\mathrm{CC}_{50}\right)$ was defined as the antimicrobial concentration required to reduce cell viability by $50 \%$ compared to untreated control. CC $_{50}$ of each compound was determined by regression analysis for both cell lines, RBC and HEp-2 tumor cells.

\section{Statistical Method}

Results of MIC and time kill assay were analyzed using Wilcoxon or Kruskal-Wallis test followed by Dunn's test. Analyses were performed using R Statistical Software, version 3.1.0 (Foundation for Statistical Computing, Vienna, Austria). Values of $p<0.05$ were considered significant.

\section{RESULTS}

\section{Bio-AgNP Characterization}

Average bio-AgNP size and zeta potential were $77.68 \mathrm{~nm}$ and $-34.6 \mathrm{mV}$, respectively (Supplementary Material).

\section{MIC and Antimicrobial Interaction}

OEO and bio-AgNP inhibited the growth of all bacterial strains tested, including multidrug-resistant strains. The mean MIC for $\mathrm{OEO}$ was $0.526 \pm 0.130 \mathrm{mg} / \mathrm{mL}$, and the mean $\mathrm{MBC}$ was $0.500 \pm$ $0.158 \mathrm{mg} / \mathrm{mL}, \mathrm{MIC}$ and MBC ranged from 0.298 to $1.193 \mathrm{mg} / \mathrm{mL}$ (Table 2). The mean MIC for bio-AgNP was $129.17 \pm 55.25 \mu \mathrm{M}$ ranging from 62.5 to $250 \mu \mathrm{M}$, and the mean $\mathrm{MBC}$ was $154.17 \pm$ $110.46 \mu \mathrm{M}$ ranging from $62.5 \mu \mathrm{M}$ to $500 \mu \mathrm{M}$ (Table 2).

There was no statistical difference between standard and multidrug-resistant strains with regard to MIC values of the two individual compounds $(p>0.05)$. No significant difference $(p>0.05)$ was observed between Gram-positive and Gramnegative sensitivity to OEO, where both bacterial groups were susceptible to this natural compound. Bio-AgNP showed better activity against Gram-negative bacteria $(p<0.05)$, where the mean MIC was $125 \pm 56.53 \mu \mathrm{M}$ in contrast to Gram-positive mean MIC, which was $225 \pm 55.90 \mu \mathrm{M}$.

In combination, OEO and bio-AgNP showed significantly lower MIC values when compared with individual treatment $(p<$ 0.05 ), where the two compounds together resulted in synergistic or additive antibacterial activity (Table 3 ).

\section{Time-Kill Curve}

OEO reduced the number of $\mathrm{CFU} / \mathrm{mL}$ rapidly. For all three strains tested (S. aureus ATCC 25923, E. coli ATCC 25922, KPCproducing $E$. coli), after $10 \mathrm{~min}$ of treatment with $\mathrm{OEO}$ at $\mathrm{MIC}$ $(0.596 \mathrm{mg} / \mathrm{mL})$, there were no viable cells ( $p<0.05$; Figures $1-3)$. The bacterial inhibition by OEO was immediate, where after $30 \mathrm{~s}$ of treatment, there was a $0.57 \log (p<0.05), 1.54 \log (p<$ $0.05)$, and $0.27 \log (p<0.05)$ reduction of $S$. aureus ATCC 25923 
TABLE 2 | Mean of minimal inhibitory and bactericidal concentrations of oregano essential oil and biological silver nanoparticles.

\begin{tabular}{|c|c|c|c|c|}
\hline \multirow[t]{2}{*}{ Bacteria } & \multicolumn{2}{|c|}{ OEO (mg/mL) } & \multicolumn{2}{|c|}{ bio-AgNP $(\mu \mathrm{M})$} \\
\hline & MIC & MBC & MIC & MBC \\
\hline S. aureus (ATCC 25923) & 0.596 & 0.596 & 250.0 & 250.0 \\
\hline S. mutans (ATCC 25175) & 0.596 & 0.596 & 125.0 & 250.0 \\
\hline E. coli (ATCC 25922) & 0.596 & 0.596 & 62.50 & 62.50 \\
\hline S. enterica Enteritidis (ATCC 13076) & 0.298 & 0.298 & 62.50 & 62.50 \\
\hline K. pneumoniae (ATCC 10031) & 0.596 & 0.596 & 62.50 & 62.50 \\
\hline K. pneumoniae (ATCC 700603) & 0.596 & 0.596 & 125.0 & 125.0 \\
\hline S. enterica Typhimurium UK-1* & 0.298 & 0.298 & 125.0 & 125.0 \\
\hline MRSA N315 & 0.596 & 0.596 & 250.0 & 250.0 \\
\hline MRSA 101 & 1.193 & 1.193 & 250.0 & 500.0 \\
\hline MRSA 107 & 1.193 & 1.193 & 250.0 & 500.0 \\
\hline E. coli ESBL 167 & 0.596 & 0.596 & 125.0 & 125.0 \\
\hline E. coli ESBL 169 & 0.596 & 0.596 & 125.0 & 125.0 \\
\hline E. coli ESBL 176 & 0.596 & 0.596 & 125.0 & 125.0 \\
\hline E. coli ESBL 192 & 0.596 & 0.596 & 125.0 & 125.0 \\
\hline E. coli KPC 131 & 0.596 & 0.596 & 125.0 & 125.0 \\
\hline E. coli KPC 133 & 0.596 & 0.596 & 125.0 & 125.0 \\
\hline A. baumannii CR 01 & 0.298 & 0.298 & 125.0 & 125.0 \\
\hline
\end{tabular}

OEO, oregano essential oil; bio-AgNP, biological silver nanoparticles. MIC, minimal inhibitory concentration; MBC, minimal bactericidal concentration. ATCC, American Type Culture Collection.

*, ATCC 68169.

MRSA, methicillin resistant $S$. aureus.

ESBL, extended spectrum beta-lactamase; KPC, K. pneumoniae carbapenemase. CR, Carbapenem-resistant;

$101,107,167,169,176,192,131,133$, and 01 are strain numbers at Laboratory of Basic and Applied Bacteriology-Universidade Estadual de Londrina.

(Figure 1), E. coli ATCC 25922 (Figure 2), and carbapenemaseproducing E. coli (Figure 3) cell populations, respectively.

Bio-AgNP at MIC $(250 \mu \mathrm{M})$ showed bactericidal effect at $24 \mathrm{~h}$ to $S$. aureus ATCC 25923 ( $p<0.05$; Figure 1). After $10 \mathrm{~h}$ of treatment, the $S$. aureus cell population decreased by $0.57 \log (p<$ $0.05)$; and between 10 and $24 \mathrm{~h}$ of treatment, there was a $4.73 \mathrm{log}$ reduction $(p<0.05)$. Gram-negative bacteria lost total viability after $4 \mathrm{~h}$ of incubation with bio-AgNP at 62.5 and $125 \mu \mathrm{M}$ for E. coli ATCC 25922 (Figure 2) and carbapenemase-producing $E$. coli (Figure 3), respectively ( $p<0.05$ ). In both Gram-negative bacteria, after $2 \mathrm{~h}$ of exposure to bio-AgNP, there was a significant decrease in CFU/mL, 3.3 and $2.31 \log$ reduction in standard $E$. coli (Figure 2) and KPC-producing E. coli (Figure 3), respectively $(p<0.05)$.

The combination of OEO and bio-AgNP led to faster reduction of $\mathrm{CFU} / \mathrm{mL}$ than in individual treatment with bioAgNP. Against S. aureus ATCC 25923, the combination of the two compounds at synergistic MIC $(0.149 \mathrm{mg} / \mathrm{mL}$ and 62.5 $\mu \mathrm{M}$ for OEO and bio-AgNP, respectively) showed bacteriostatic activity (data not shown). But the combination with additive MIC values $(0.298 \mathrm{mg} / \mathrm{mL}$ OEO and $125 \mu \mathrm{M}$ bio-AgNP) against $S$. aureus ATCC 25923 caused a $3.48 \mathrm{log}$ decrease in cell population in $2 \mathrm{~h}(p<0.05)$ and resulted in no viable bacterial cells at $7 \mathrm{~h}(p$ $<0.05$; Figure 1).
TABLE 3 | Combinatory effect of oregano essential oil and biological silver nanoparticles and both minimal inhibitory concentrations in combination.

\begin{tabular}{|c|c|c|c|}
\hline \multirow[b]{2}{*}{ Bacteria } & \multicolumn{2}{|c|}{ MIC } & \multirow[t]{2}{*}{$\mathrm{FICl}$} \\
\hline & OEO $(\mathrm{mg} / \mathrm{mL})$ & Bio-AgNP $(\mu \mathrm{M})$ & \\
\hline S. aureus (ATCC 25923) & 0.149 & 62.50 & $0.50(S)$ \\
\hline S. mutans (ATCC 25175) & 0.075 & 62.50 & $0.62(A)$ \\
\hline E. coli (ATCC 25922) & 0.298 & 15.62 & $0.75(A)$ \\
\hline S. enterica Enteritidis (ATCC 13076) & 0.037 & 31.25 & $0.62(\mathrm{~A})$ \\
\hline K. pneumoniae (ATCC 10031) & 0.075 & 15.62 & $0.37(S)$ \\
\hline K. pneumoniae (ATCC 700603) & 0.075 & 62.50 & $0.62(\mathrm{~A})$ \\
\hline S. enterica Typhimurium UK-1* & 0.149 & 62.50 & $1.00(A)$ \\
\hline MRSA N315 & 0.075 & 125.0 & $0.62(\mathrm{~A})$ \\
\hline MRSA 101 & 0.596 & 62.50 & $0.75(A)$ \\
\hline MRSA 107 & 0.596 & 62.50 & $0.75(A)$ \\
\hline E. coli ESBL 167 & 0.149 & 15.62 & $0.37(S)$ \\
\hline E. coli ESBL 169 & 0.149 & 15.62 & $0.37(S)$ \\
\hline E. coli ESBL 176 & 0.149 & 31.25 & $0.50(S)$ \\
\hline E. coli ESBL 192 & 0.149 & 31.25 & $0.50(S)$ \\
\hline E. coli KPC 131 & 0.075 & 31.25 & $0.37(\mathrm{~S})$ \\
\hline E. coli KPC 133 & 0.075 & 62.50 & $0.62(\mathrm{~A})$ \\
\hline A. baumannii CR 01 & 0.149 & 15.62 & $0.62(\mathrm{~A})$ \\
\hline
\end{tabular}

OEO, oregano essential oil; bio-AgNP, biological silver nanoparticles.

ATCC, American Type Culture Collection.

*, S. enterica Typhimurium ATCC 68169.

MRSA, methicillin resistant $S$. aureus.

ESBL, extended spectrum beta-lactamase; KPC, K. pneumoniae carbapenemase. CR, Carbapenem-resistant.

101, 107, 167, 169, 176,192, 131, 133 and 01 are strain numbers at Laboratory of Basic and Applied Bacteriology-Universidade Estadual de Londrina.

$\mathrm{FlCl}$, fractional inhibitory concentration index.

FIC index were interpreted as follows: $\leq 0.5$, synergy; $>0.5$ to 1.0 , addition; $>1.0$ to < 4.0, indifference; and $\geq 4$, antagonism.

(S), Synergistic interaction; (A), Additive interaction.

Against standard E. coli (ATCC 25922), OEO and bio-AgNP at additive MIC $(0.298 \mathrm{mg} / \mathrm{mL}$ and $15.62 \mu \mathrm{M}$, respectively) caused a $2.3 \log$ decrease $(p<0.05)$ within $10 \mathrm{~min}$ of treatment and there were no viable cells after $20 \mathrm{~min}(p<0.05$; Figure 2$)$. At 30 min of incubation with synergistic MIC values $(0.075 \mathrm{mg} / \mathrm{mL}$ and $31.25 \mu \mathrm{M}$ for OEO and bio-AgNP, respectively), the population of carbapenemase-producing E. coli decreased $2.7 \log (p<0.05)$ and after $2 \mathrm{~h}$ there was a total reduction of bacterial population $(p<0.05$; Figure 3).

\section{Scanning Electron Microscopy}

To investigate antimicrobial activity against $S$. aureus ATCC 25923 (non-MRSA) by OEO, bio-AgNP and combination of the two treatment, the morphology changes were investigated with SEM. Untreated cells showed their unique shapes (spherical shaped) $30 \mathrm{~min}$ (Figure 4A) and $6 \mathrm{~h}$ (Figure 4B) after incubation. Inset images showed, seen clearly in the higher magnification, intact surface of S. aureus ATCC 25923 (Figures 4A,B - inset). Although cells treated after $30 \mathrm{~min}$ with OEO alone was still present, most of them were damaged and extensively disappeared (Figure 4C). Inset showed details, in higher magnification, of morphological changes on the cells surface (Figure 4C - inset). Treatment with bio-AgNP alone after $6 \mathrm{~h}$ showed a decrease 


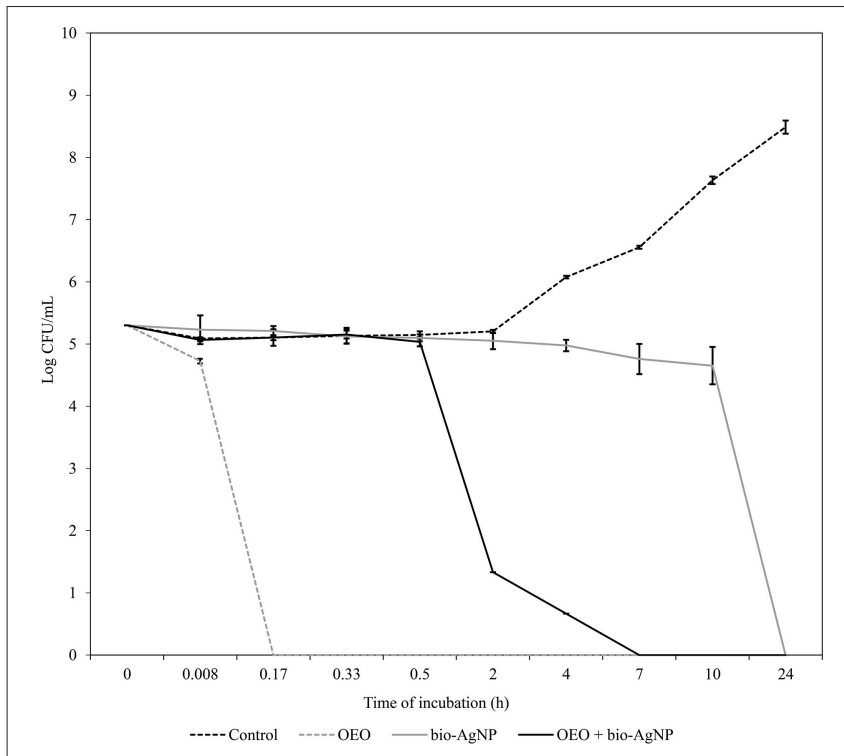

FIGURE 1 | Time-kill curves of S. aureus 25923 (ATCC) exposed to OEO and bio-AgNP individually and in combination at MIC values. Bacteria at $5 \times 10^{5} \mathrm{CFU} / \mathrm{mL}$ were exposed to three different treatments; OEO alone $(0.596 \mathrm{mg} / \mathrm{mL})$, bio-AgNP alone $(250 \mu \mathrm{M})$, and OEO + bio-AgNP (0.298 $\mathrm{mg} / \mathrm{mL}+125 \mu \mathrm{M})$. Control indicates bacterial growth without antimicrobial compounds. Values of $\mathrm{CFU} / \mathrm{mL}$ are the mean \pm standard deviation.

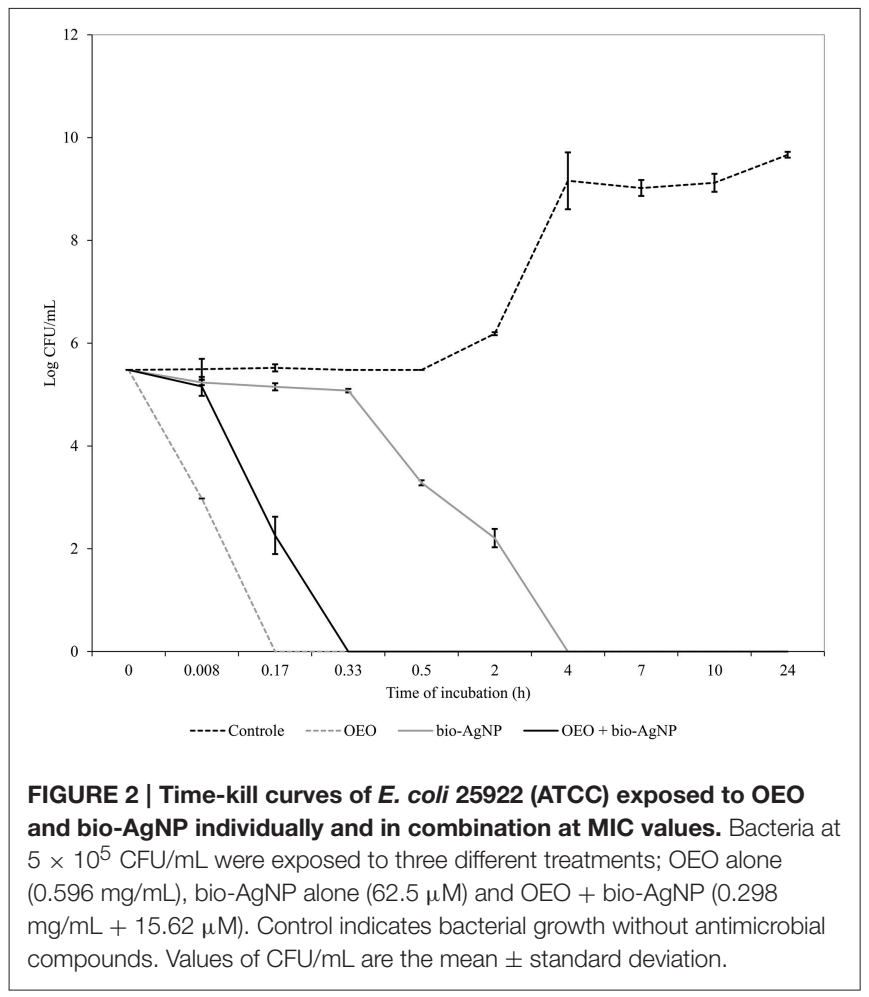

in cell density and caused morphological changes (Figure 4D). Inset show, in the higher magnification, cells walls covered with substance resulting from serious disruptions in the surface

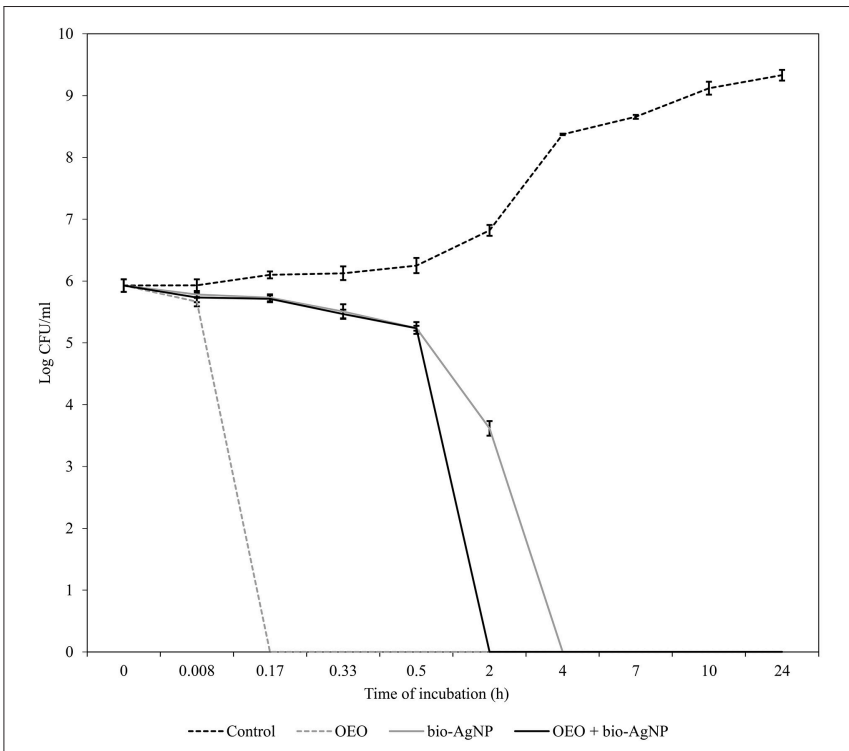

FIGURE 3 | Time-kill curves of carbapenemase-producing E. coli exposed to OEO and bio-AgNP individually and in combination at MIC values. Bacteria at $5 \times 10^{5} \mathrm{CFU} / \mathrm{mL}$ were exposed to three different treatments; OEO alone $(0.596 \mathrm{mg} / \mathrm{mL})$, bio-AgNP alone $(125 \mu \mathrm{M})$, and OEO + bio-AgNP $(0.075 \mathrm{mg} / \mathrm{mL}+31.25 \mu \mathrm{M})$. Control indicates bacterial growth without antimicrobial compounds. Values of CFU $/ \mathrm{mL}$ are the mean \pm standard deviation.

of S. aureus ATCC 25923 (Figure 4D - inset). Cells treated with combination of OEO plus bio-AgNP (Figure 4E) showed very deformed cells, with cell debris and damages appeared as cell surface blebbing after $6 \mathrm{~h}$ treatment (Figure 4E - inset). Treatments with OEO plus bio-AgNP showed a decrease in cell density, exopolysaccharide, morphology changes, and cell destruction, compared to the non-treated cells. It indicated that this composition have an antimicrobial activity against $S$. aureus by disrupting cells.

\section{Cytotoxicity Assay in Human RBC and HEp-2 cells}

Results of MTT assay showed that OEO was toxic to tumor cells (HEp-2 cells), reducing cell metabolism by $50 \%$ or more at concentrations higher than $0.075 \mathrm{mg} / \mathrm{mL}$ (Figure 5A). But this essential oil was less toxic to $\mathrm{RBC}$, and the $\mathrm{CC}_{50}$ was $7.519 \mathrm{mg} / \mathrm{mL}$ (Figure 6A). $\mathrm{CC}_{50}$ of bio-AgNP in HEp-2 cells was $97.22 \mu \mathrm{M}$ (Figure 5B), and very low hemolytic activity was observed even at the highest concentration tested $(250 \mu \mathrm{M}$; Figure 6B).

The compounds in combination were non-toxic to HEp2 cells at concentrations of $0.075 \mathrm{mg} / \mathrm{mL}$ and $31.25 \mu \mathrm{M}$ to $\mathrm{OEO}$ and bio-AgNP respectively, or at lower values concentrations. The combination of $0.075 \mathrm{mg} / \mathrm{mL}$ of $\mathrm{OEO}$ and $125 \mu \mathrm{M}$ or $62.5 \mu \mathrm{M}$ of bio-AgNP showed toxicity to HEp-2 cells (Table 4). However, the combination of OEO and bio-AgNP was non-toxic to RBC at all concentrations tested (Table 5). 

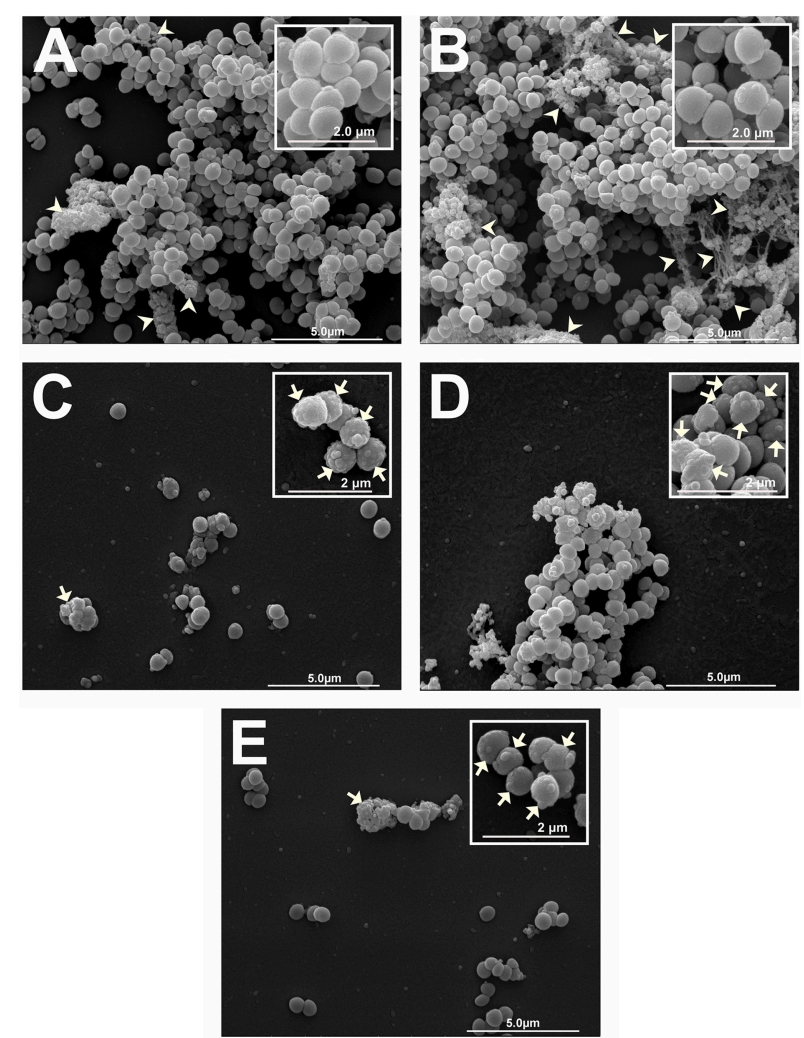

FIGURE 4 | Scanning electron micrograph of antibacterial effect of OEO and bio-AgNP alone and in combination against S. aureus ATCC 25923 (non-MRSA). (A) Untreated control after 30 min incubation. (B) Untreated control after $6 \mathrm{~h}$ incubation. (C) Treated cells with OEO at 0.596 $\mathrm{mg} / \mathrm{mL}$ for $30 \mathrm{~min}$. (D) Treated cells with bio-AgNP at $250 \mu \mathrm{M}$ for $6 \mathrm{~h}$. (E) Treated cells with combination of OEO and bio-AgNP at $0.298 \mathrm{mg} / \mathrm{mL}$ and $125 \mu \mathrm{M}$, respectively, for $6 \mathrm{~h}$. Micrographs (A-E) show cell density and exopolysaccharide matrix (15,000 x). Inset images show detail of morphological alterations of treated cells and typical cell morphology of untreated controls (30,000 x). Arrows: morphological changes (surface protrusions) and cellular debris. Arrowheads: exopolysaccharide.

\section{DISCUSSION}

This study showed that OEO has potent bactericidal activity at low concentration with fast action, in agreement with previous studies (Burt and Reinders, 2003; Souza et al., 2010; Betancourt et al., 2012; Alvarez et al., 2014). Busatta et al. (2007) reported for OEO MIC values of 0.23 and $0.46 \mathrm{mg} / \mathrm{mL}$ against methicillin-sensitive $S$. aureus and E. coli ATCC 25922 respectively. Betancourt et al. (2012) found for OEO a MIC of $0.780 \mathrm{mg} / \mathrm{mL}$ against $S$. enterica and $3.125 \mathrm{mg} / \mathrm{mL}$ against E. coli. OEO MIC values obtained in our study ranged from 0.298 to $1.193 \mathrm{mg} / \mathrm{mL}$ (Table 2), which were in line with literature results. Our analysis showed that OEO at a low concentration was bactericidal against all multidrug-resistant bacteria tested, with $\mathrm{MBC}$ values of $0.298 \mathrm{mg} / \mathrm{mL}$ against A. baumannii, $0.596 \mathrm{mg} / \mathrm{mL}$ against ESBL and KPC-producing E. coli isolates and $1.193 \mathrm{mg} / \mathrm{mL}$ against both clinical MRSA isolates.

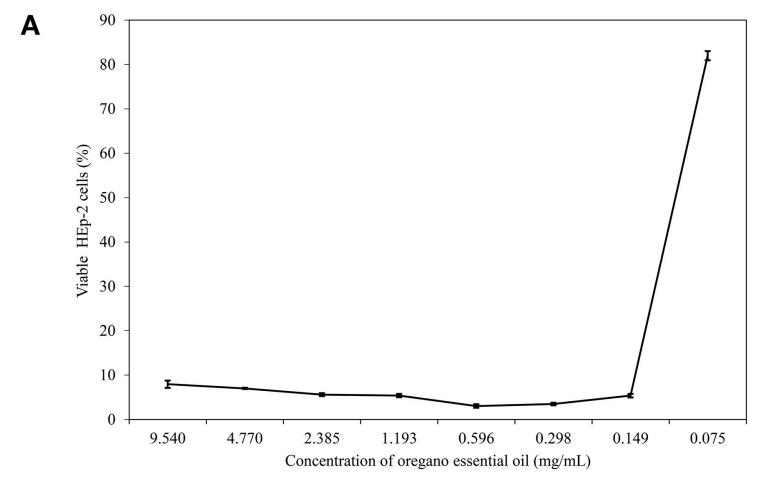

B

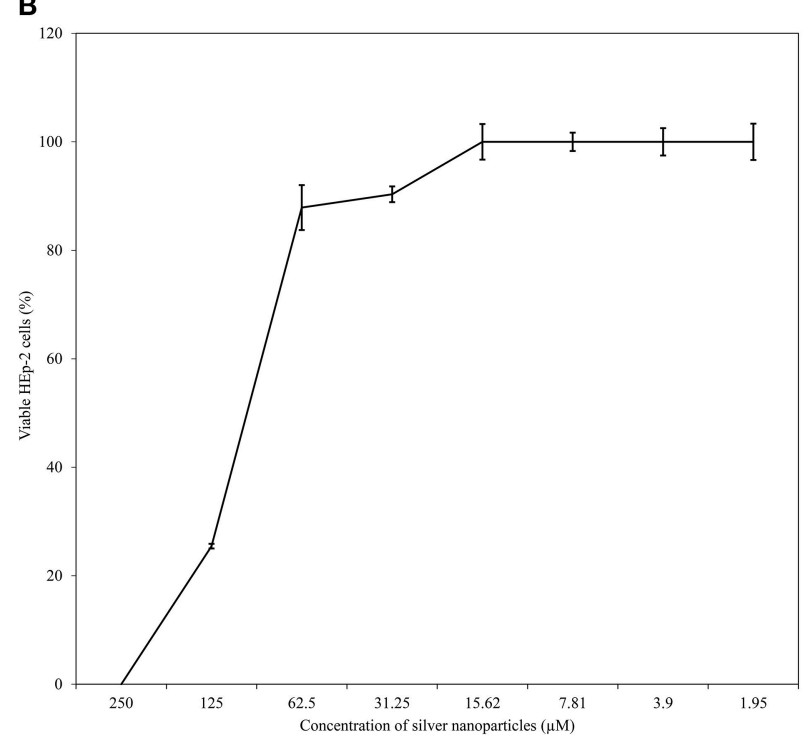

FIGURE 5 | HEp-2 cell viability at different concentrations of OEO and bio-AgNP individually. (A) HEp-2 cell exposed to $\mathrm{OEO}$ alone ranging from 0.075 to $9.540 \mathrm{mg} / \mathrm{mL}$. (B) HEp-2 cell exposed to bio-AgNP alone ranging from 1.95 to $250 \mu \mathrm{M}$. Percentage values of cell viability are the mean \pm standard deviation.

Time-kill assays showed that OEO reduced cell populations nearly $5 \log$ (after $10 \mathrm{~min}$ of treatment) in all three bacterial strains tested $(p<0.05)$, so our results indicated that OEO acted within a few minutes against $S$. aureus ATCC 25923 (Figure 1), E. coli ATCC 25922 (Figure 2), and KPC-producing E. coli (Figure 3). Burt and Reinders (2003) showed that when E. coli $\mathrm{O} 157: \mathrm{H} 7$ at $5 \times 10^{5} \mathrm{CFU} / \mathrm{mL}$ were exposed to $\mathrm{OEO}(0.06 \%, \mathrm{v} / \mathrm{v})$, there were no viable cells after $1 \mathrm{~min}$ of treatment. In a study with S. aureus isolated from food, Barros et al. (2009) found that $\mathrm{OEO}$ at MIC $(0.06 \%, \mathrm{v} / \mathrm{v})$ caused $3 \log$ reduction of initial inoculum $\left(10^{8} \mathrm{CFU} / \mathrm{mL}\right)$ after $2 \mathrm{~h}$ of treatment. In our study using an equal initial inoculum (S. aureus at $10^{8} \mathrm{CFU} / \mathrm{mL}$ ) and same OEO concentration $(0.596 \mathrm{mg} / \mathrm{mL}$; corresponding to 0.06 $\%, \mathrm{v} / \mathrm{v})$, there were no viable cells after $30 \mathrm{~min}(p<0.05)$, due to a $8 \log$ reduction of S. aureus ATCC 25923 population (data not shown).

Some studies have found that terpenoid compounds from $\mathrm{OEO}$ are more active against Gram-positive bacteria 


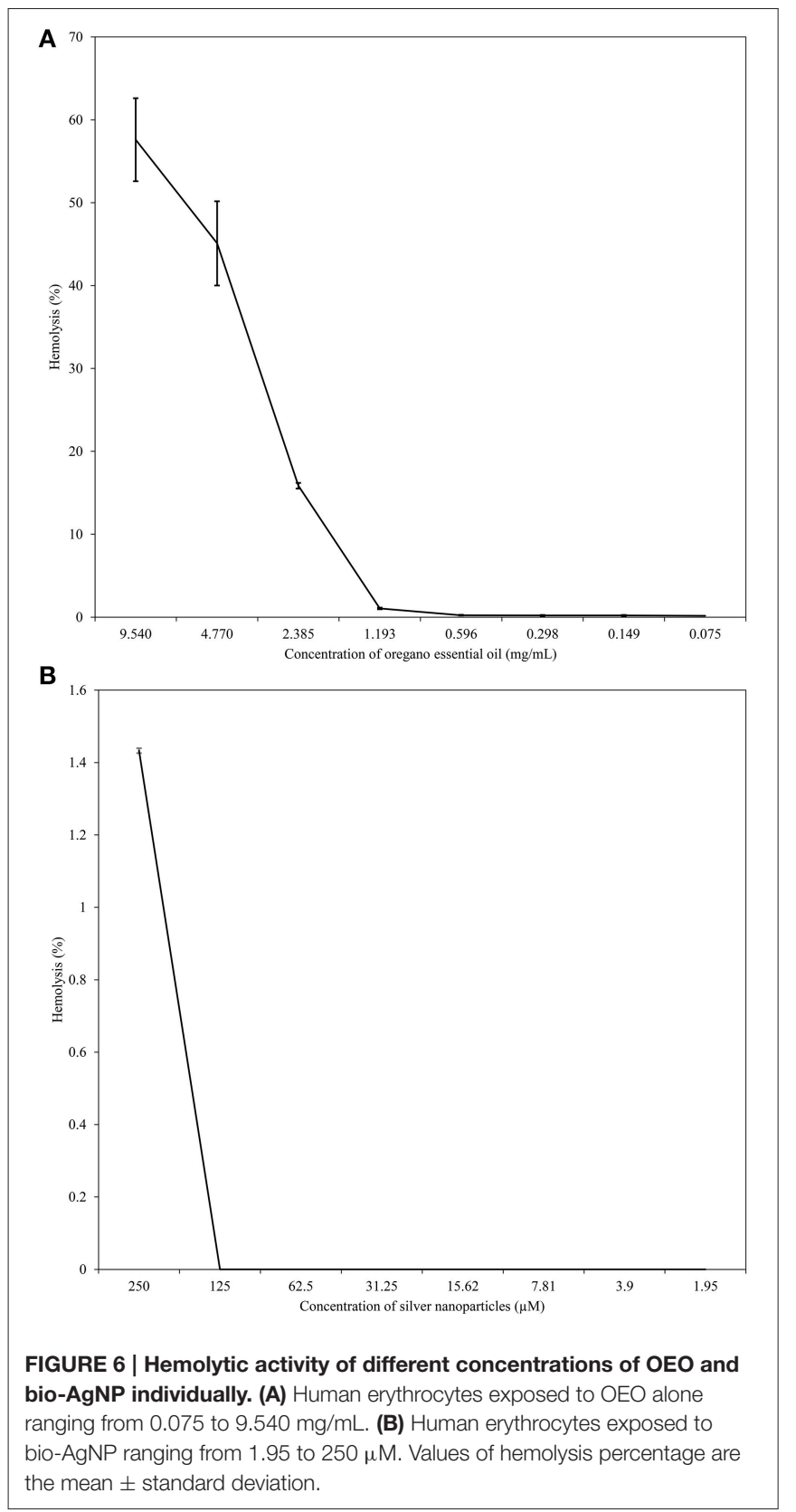

(Smith-Palmer et al., 1998; Lambert et al., 2001; Stojković et al., 2013). Our results indicated that OEO has broadspectrum action in agreement with previous studies (Busatta et al., 2007; Rosato et al., 2010; Stojković et al., 2013; Alvarez et al., 2014), where it was equally effective according to MIC (Table 2) and time of action (Figures 1-3) against Gram-positive and Gram-negative bacteria $(p>0.05)$; these results are in line with those obtained by other researchers (Dorman and Deans, 2000; Rosato et al., 2010). This variable susceptibility of bacteria to essential oils can be due to the chemical composition of essential oils, which varies according to seasonal and geographical factors (Medini et al., 2009).
TABLE 4 | HEp-2 cell viability at different concentrations of oregano essential oil (OEO) and biological silver nanoparticles (bio-AgNP) in combination.

\begin{tabular}{|c|c|c|c|}
\hline \multirow{2}{*}{ Combination } & \multicolumn{2}{|c|}{ Tested concentrations } & \multirow[t]{2}{*}{ Viable cells (\%) } \\
\hline & OEO (mg/mL) & bio-AgNP $(\mu \mathrm{M})$ & \\
\hline $\mathrm{A} 1$ & 0.596 & 125.0 & $0.95 \pm 0.69$ \\
\hline A2 & 0.596 & 62.50 & $1.36 \pm 0.59$ \\
\hline A3 & 0.596 & 31.25 & $0.99 \pm 0.15$ \\
\hline A4 & 0.596 & 15.62 & $1.27 \pm 0.40$ \\
\hline B1 & 0.298 & 125.0 & $1.18 \pm 0.20$ \\
\hline B2 & 0.298 & 62.50 & $1.72 \pm 0.57$ \\
\hline B3 & 0.298 & 31.25 & $1.04 \pm 0.20$ \\
\hline B4 & 0.298 & 15.62 & $1.99 \pm 4.64$ \\
\hline $\mathrm{C} 1$ & 0.149 & 125.0 & $7.80 \pm 2.00$ \\
\hline $\mathrm{C} 2$ & 0.149 & 62.50 & $21.81 \pm 12.19$ \\
\hline C3 & 0.149 & 31.25 & $22.94 \pm 14.00$ \\
\hline $\mathrm{C} 4$ & 0.149 & 15.62 & $72.01 \pm 17.60^{\mathrm{NC}}$ \\
\hline D1 & 0.075 & 125.0 & $38.68 \pm 8.49$ \\
\hline D2 & 0.075 & 62.50 & $51.61 \pm 3.25$ \\
\hline D3 & 0.075 & 31.25 & $94.24 \pm 3.67 \mathrm{NC}$ \\
\hline D4 & 0.075 & 15.62 & $100 \pm 0.00^{N C}$ \\
\hline E1 & 0.037 & 125.0 & $61.54 \pm 6.92^{\mathrm{NC}}$ \\
\hline E2 & 0.037 & 62.50 & $82.27 \pm 10.55^{\mathrm{NC}}$ \\
\hline E3 & 0.037 & 31.25 & $100 \pm 0.00^{N C}$ \\
\hline E4 & 0.037 & 15.62 & $100 \pm 0.00^{\mathrm{NC}}$ \\
\hline
\end{tabular}

Concentrations of OEO (mg/mL) in combination: $A, 0.596 ; B, 0.298 ; C, 0.149 ; D, 0.075$; E, 0.037 .

Concentrations of bio-AgNP ( $\mu M$ ) in combination: (1) 125; (2) 62.5; (3) 31.25; (4) 15.62. NC, non-cytotoxic, \pm , standard deviation.

Many studies suggest that essential oils affect the bacterial cell membrane resulting in growth inhibition, since this structure supports the most essential functions in prokaryotes. Bennis et al. (2004) reported cell surface changes such as curling and cracks in Saccharomyces cerevisiae treated with thymol. Lambert et al. (2001) suggested that OEO inhibits bacterial growth due to damage to membrane integrity, affecting $\mathrm{pH}$ homeostasis and equilibrium of inorganic ions. Suzuki et al. (2015) found physical damage and morphological alterations in Staphylococcus epidermidis treated with OEO products. Souza et al. (2010) showed loss of $260 \mathrm{~nm}$-absorbing material and release of potassium ions of $S$. aureus cells treated with $\mathrm{OEO}$, results suggesting increased membrane permeability. In our study, SEM observations confirmed physical damage and considerable morphological alteration as cell surface blebbing in S. aureus ATCC 25923 (non-MRSA) cells exposed to OEO for 30 min (Figure 4C), compared to control (untreated bacteria) showing no morphological changes after $30 \mathrm{~min}$ (Figure 4A). This analysis by electron microscopy revealed a decrease in cell density of OEO-treated bacteria sample when compared to control sample, according with time kill results at $30 \mathrm{~min}$ of incubation (data not shown).

In our RBC toxicity assay, OEO $\mathrm{CC}_{50}$ was $7.519 \mathrm{mg} / \mathrm{mL}$ (Figure 6A). OEO did not appear to be toxic to RBC, since MIC values ranged from $0.037 \mathrm{mg} / \mathrm{mL}$ to $1.193 \mathrm{mg} / \mathrm{mL}$ (Tables 2, 3). 
TABLE 5 | Hemolytic activity of oregano essential oil (OEO) and biological silver nanoparticles (bio-AgNP) in combination.

\begin{tabular}{|c|c|c|c|}
\hline \multirow[t]{2}{*}{ Combination } & \multicolumn{2}{|c|}{ Tested concentrations } & \multirow[t]{2}{*}{ Hemolysis (\%) } \\
\hline & OEO $(\mathrm{mg} / \mathrm{mL})$ & bio-AgNP $(\mu \mathrm{M})$ & \\
\hline A1 & 0.596 & 125.0 & $6.49 \pm 2.29 \mathrm{NC}$ \\
\hline A2 & 0.596 & 62.50 & $2.86 \pm 0.11^{\mathrm{NC}}$ \\
\hline A3 & 0.596 & 31.25 & $1.95 \pm 0.11^{\mathrm{NC}}$ \\
\hline A4 & 0.596 & 15.62 & $0.49 \pm 0.13^{\mathrm{NC}}$ \\
\hline B1 & 0.298 & 125.0 & $7.56 \pm 1.16^{\mathrm{NC}}$ \\
\hline B2 & 0.298 & 62.50 & $2.60 \pm 1.33^{\mathrm{NC}}$ \\
\hline B3 & 0.298 & 31.25 & $0.77 \pm 0.37^{\mathrm{NC}}$ \\
\hline B4 & 0.298 & 15.62 & $0.19 \pm 0.32^{\mathrm{NC}}$ \\
\hline C1 & 0.149 & 125.0 & $8.44 \pm 0.98^{\mathrm{NC}}$ \\
\hline C2 & 0.149 & 62.50 & $4.58 \pm 0.23^{\mathrm{NC}}$ \\
\hline C3 & 0.149 & 31.25 & $0.19 \pm 0.17^{\mathrm{NC}}$ \\
\hline C4 & 0.149 & 15.62 & $1.26 \pm 0.19^{\mathrm{NC}}$ \\
\hline D1 & 0.075 & 125.0 & $7.75 \pm 0.93^{\mathrm{NC}}$ \\
\hline D2 & 0.075 & 62.50 & $2.67 \pm 0.73^{\mathrm{NC}}$ \\
\hline D3 & 0.075 & 31.25 & $0.42 \pm 0.13^{\mathrm{NC}}$ \\
\hline D4 & 0.075 & 15.62 & $0.00 \pm 0.00^{\mathrm{NC}}$ \\
\hline E1 & 0.037 & 125.0 & $5.81 \pm 2.27^{\mathrm{NC}}$ \\
\hline E2 & 0.037 & 62.50 & $1.57 \pm 0.27^{\mathrm{NC}}$ \\
\hline E3 & 0.037 & 31.25 & $0.42 \pm 0.53^{\mathrm{NC}}$ \\
\hline E4 & 0.037 & 15.62 & $0.00 \pm 0.00^{\mathrm{NC}}$ \\
\hline
\end{tabular}

Concentrations of $O E O(\mathrm{mg} / \mathrm{mL})$ in combination: $A, 0.596 ; B, 0.298 ; C, 0.149 ; D, 0.075$; E, 0.037 .

Concentrations of bio-AgNP ( $\mu M$ ) in combination: (1) 125; (2) 62.5; (3) 31.25; (4) 15.62. NC, non-cytotoxic, \pm , standard deviation.

The lack of cytotoxicity of OEO to erythrocytes has also been found by other investigators. Mancini et al. (2014) reported no hemolytic activity of OEO against bovine erythrocytes, and Cacciatore et al. (2015) showed that carvacrol derivatives did not produce human blood hemolysis at their MIC values. OEO was toxic to HEp-2 cells (Figure 5A), and there are previous studies using tumor cells, including HEp-2 cells, that reported the antitumor activity of OEO or its components (Mehdi et al., 2011; Gautam et al., 2014; Sobral et al., 2014).

Due to its strong antimicrobial property, OEO has potential to replace antibiotics in the food industry and can be incorporated in cosmetic products, among other applications (Alvarez et al., 2014; Suzuki et al., 2015). However, the high volatile character and undesirable organoleptic features can limit its use; therefore, alternatives to solve these limitations are required (Burt, 2004; Alvarez et al., 2014; Hernández-Hernández et al., 2014).

In this study, bio-AgNP exhibited broad-spectrum antibacterial action, inhibiting growth of both Gram-positive and -negative bacteria, in agreement with the literature (Busatta et al., 2007; Jain et al., 2009; Kim et al., 2011). The mean MIC value obtained in our study $(129 \mu \mathrm{M})$ was according with previous studies using silver nanoparticles produced by F. oxysporum that reported MIC value of $125 \mu \mathrm{M}$ (Cardozo et al., 2013; Biasi-Garbin et al., 2015). However, we found that Gram-positive bacteria were more tolerant to silver nanoparticles because
bio-AgNP MIC values were higher (Table 2) and time of action was slower, compared to Gram-negative bacteria (Figures 1-3), as reported in other studies (Jain et al., 2009; Durán et al., 2010; Agnihotri et al., 2014). Kim et al. (2011) showed that Gramnegative bacteria were more susceptible to silver nanoparticles compared to Gram-positive strains, where there was increased bactericidal activity in time kill assay, loss of protein through the membrane and inactivation of lactate dehydrogenase (LDH), besides marked morphological changes.

The size of the nanoparticles is a key point in their antibacterial activity, where many studies show that antibacterial activity is particle size dependent; antimicrobial activity of nanoparticles increases with smaller size (Panacek et al., 2006; Ayala-Núñez et al., 2009; Agnihotri et al., 2014), and this fact accounts for the variation in MIC data between different studies, limiting comparison.

Our analysis by SEM showed surface protrusions on bioAgNP treated $S$. aureus cells (non-MRSA) (Figure 4D). Kim et al. (2011) reported that bacterial cells treated with silver nanoparticles had irregular fragments on the surface, a large protein leakage and decrease in bacterial growth; suggesting that fragments can be lost cytoplasmic material resulting in damage to the membrane with a consequent increase in permeability. Studies also report that silver ions have an affinity for thiol groups and may damage respiratory enzymes of cytoplasmic membrane (Holt and Bard, 2005; Li et al., 2010).

In our RBC toxicity assay, bio-AgNP were not cytotoxic to human blood cells (Figure 6B). Our metal compound did not exhibit cytotoxic effect on $\mathrm{RBC}$ at the concentrations studied, $250 \mu \mathrm{M}(37.5 \mu \mathrm{g} / \mathrm{mL})$ to $1.95 \mu \mathrm{M}(0.29 \mu \mathrm{g} / \mathrm{mL})$, so it was not possible to calculate CC50 for human erythrocytes. Spectrophotometric analysis of supernatants indicated that bioAgNP did not increase absorbance, demonstrating that little hemoglobin was released from the RBC. Choi et al. (2011) showed that the silver nanoparticles at $700 \mu \mathrm{g} / \mathrm{mL}$ lysed $50 \%$ of RBC. According to ASTM E2524-08 (2013) ${ }^{1}$ standards, hemolysis $>5 \%$ indicates damage to RBC; in our study, the highest bio-AgNP concentration tested $(250 \mu \mathrm{M})$ showed only $1.4 \%$ hemolysis. Our MTT assay results showed that bioAgNP was toxic to HEp-2 cells only at high concentrations (CC50 $=97.22 \mu \mathrm{M})$, often above that needed to inhibit bacterial growth. Some authors have reported antitumor activity of silver nanoparticles, supporting our finding of bio-AgNP being more toxic to HEp-2 cells than to RBC (Devi and Bhimba, 2012; Antony et al., 2013).

Despite the effective antimicrobial action of bio-AgNP with broad spectrum activity and low cytotoxicity, bacteria can easily develop resistance to these nanoparticles by simple genetic changes (Graves et al., 2015). Thus, alternative studies to work around this problem are needed.

Combined drug treatment is recommended as a strategy to control antimicrobial resistance (Fischbach, 2011; Bollenbach, 2015). Li et al. (2005) observed a synergistic effect of silver

\footnotetext{
${ }^{1}$ ASTM E2524-08 (2013). Standard Test Method for Analysis of Hemolytic Properties of Nanoparticles. Available online at: http://www.astm.org/Standards/ E2524.htm [Accessed October 17, 2015].
} 
nanoparticles combined with amoxicillin against E. coli, and other studies have shown a synergistic interaction with other natural alternative compounds such as cinnamaldehyde (Ghosh et al., 2013), eugenol (Biasi-Garbin et al., 2015), and phenazine1-carboxamide (Cardozo et al., 2013).

Other studies have shown that the OEO acts in synergism with some conventional antimicrobials such as gentamicin against S. aureus 29213, E. coli 25922, and A. baumannii 19606 (Rosato et al., 2010), or has an additive effect in combination with amoxicillin, polymyxin, and lincomycin against ESBL-producing E. coli (Si et al., 2008). OEO shows synergistic effects with natural substances such as essential oil of Thymus vulgare and Rosmarinus officinalis (Stojković et al., 2013; Honório et al., 2015).

In the literature, OEO (Nostro et al., 2004; Si et al., 2008; Amrouni et al., 2014) and silver nanoparticles (Cardozo et al., 2013; Singh et al., 2014; Subashini et al., 2014) were shown to be active against multidrug-resistant bacteria. But this study showed, for the first time, synergistic and additive effects of a combination of OEO and bio-AgNP against bacterial strains, including MRSA and beta-lactamaseor carbapenemase-producing bacteria. Synergistic and additive drug interactions may be potential strategies for controlling resistance evolution, since administration of multiple drugs may disrupt several bacterial functions and thus minimize selection of resistant strains (Yeh et al., 2009; Bollenbach, 2015). In combination, both compounds were effective at concentrations that individually do not affect human erythrocyte (Figure 5), and their synergistic or additive effects neither impact such cells (Table 5). However, OEO combined with bio-AgNP was cytotoxic to HEp-2 (Table 4); as observed for these compounds individually. The combination also showed antibacterial activity in short time (Figures 1-3). Furthermore, the undesirable organoleptic characteristics of OEO are decreased, since the synergistic or additive interaction reduces the concentration of both compounds.

Our results highlight the powerful action of OEO combined with bio-AgNP against Gram-negative bacteria, including those producing ESBL and carbapenemases (Table 3, Figures 2, 3). The combination of the two substances also showed activity against Gram-positive bacteria, since the FICI indicated synergistic and additive interactions (Table 3), and SEM confirmed this antimicrobial action through changes in the $S$. aureus (non-MRSA) cell surface and decrease in cell density (Figure 4E) compared to control (Figure 4B).

\section{REFERENCES}

Agnihotri, S., Mukherji, S., and Mukherji, S. (2014). Size-controlled silver nanoparticles synthesized over the range $5-100 \mathrm{~nm}$ using the same protocol and their antibacterial efficacy. RSC Adv. 4, 3974-3983. doi: 10.1039/C3RA44507K

Alexander, J. W. (2009). History of the medical use of silver. Surg. Infect. 10, 289-292. doi: 10.1089/sur.2008.9941

Alvarez, M. V., Ortega-Ramirez, L. A., Gutierrez-Pacheco, M. M., BernalMercado, A. T., Rodriguez-Garcia, I., Gonzalez-Aguilar, G. A., et al.
In conclusion, the combination of bio-AgNP with OEO resulted in synergistic and additive antimicrobial activities against the multidrug-resistant bacterial strains of $E$. coli, A. baumannii and MRSA. Therefore bio-AgNP combined with OEO has potential to be applied in industry (cosmetics, food and pharmaceutical, for example) and clinical and hospital settings (i.e., for treating wounds and burns infections, or for disinfecting hospital to combat resistant strains as A. baumannii).

\section{AUTHOR CONTRIBUTIONS}

SS, conception and drafting of the work, analysis and interpretation of results, writing of this manuscript. LD, conception of the work, analysis of the results (especially with essential oil assays and time-kill curves), review critically of this manuscript. CC, conception and analysis of MTT assay. SY, conception and analysis of MTT assay. CN, design of SEM methodology, image acquisition, analysis and interpretation of SEM results. AD, design of SEM methodology, image acquisition, analysis and interpretation of SEM results. CA, design of SEM methodology, image acquisition, analysis, and interpretation of SEM results. ND, biosynthesis and characterization of silver nanoparticles. GN, analysis and interpretation of results, review critically of this manuscript, final approval of the manuscript version to be published. RK, design of the work, drafting the work, analysis and interpretation of results, guidance in all stages of the work, review critically, and correction of this manuscript, final approval of the manuscript version to be published.

\section{ACKNOWLEDGMENTS}

This study was supported by CNPq BIOTEC 402728/2013-0 and Postgraduate Program in Microbiology of Universidade Estadual de Londrina. SS was funded by a student scholarship from Conselho Nacional de Desenvolvimento Científico e Tecnológico (CNPq). The authors thank Dr. Carlos Nozawa for providing the HEp-2 cells. Dr. A. Leyva helped with English editing of the manuscript. Laboratory of Electron Microscopy and Microanalysis of Universidade Estadual de Londrina for performing the electron micrographs.

\section{SUPPLEMENTARY MATERIAL}

The Supplementary Material for this article can be found online at: http://journal.frontiersin.org/article/10.3389/fmicb. 2016.00760

(2014). Oregano essential oil-pectin edible films as anti-quorum sensing and food antimicrobial agents. Front. Microbiol. 5:699. doi: 10.3389/fmicb.2014. 00699

Amrouni, S., Touati, M., Hadef, Y., and Djahoudi, A. (2014). Effet de l'huile essentielle d'Origanum vulgare et de Thymus ciliatus sur Pseudomonas aeruginosa VIM-2 carbapénèmase. Phytothérapie 12, 309-313. doi: 10.1007/s10298-014-0842-x

Ansari, M. A., Khan, H. M., Khan, A. A., Cameotra, S. S., Saquib, Q., and Musarrat, J. (2014). Gum arabic capped-silver nanoparticles inhibit biofilm formation by 
multi-drug resistant strains of Pseudomonas aeruginosa. J. Basic Microbiol. 54, 688-699. doi: 10.1002/jobm.201300748

Antony, J. J., Sithika, M. A. A., Joseph, T. A., Suriyakalaa, U., Sankarganesh, A., Siva, D., et al. (2013). In vivo antitumor activity of biosynthesized silver nanoparticles using Ficus religiosa as a nanofactory in DAL induced mice model. Colloids Sur. B Biointerfaces 108, 185-190. doi: 10.1016/j.colsurfb.2013.02.041

Ayala-Núñez, N. V., Villegas, H. H. L., Turrent, L. C. I., and Padilla, C. R. (2009). Silver nanoparticles toxicity and bactericidal effect against methicillin-resistant Staphylococcus aureus: nanoscale does matter. Nanobiotechnology 5, 2-9. doi: 10.1007/s12030-009-9029-1

Barros, J. C., Conceição, M. L., Gomes Neto, N. J., Costa, A. C. V., Siqueira Júnior, J. P., and Basílio Júnior, I. D. (2009). Interference of Origanum vulgare L. essential oil on the growth and some physiological characteristics of Staphylococcus aureus strains isolated from foods. LWT Food Sci. Tech. 42, 1139-1143. doi: 10.1016/j.lwt.2009.01.010

Bass, S. N., Bauer, S. R., Neuner, E. A., and Lam, S. W. (2015). Mortality risk factors for critically III patients with carbapenem-resistant bacteremia: impact of combination antimicrobial therapy. Antimicrob. Agents Chemother. 59, 3748-3753. doi: 10.1128/AAC.00091-15

Bassolé, I. H. N., and Juliani, H. R. (2012). Essential oils in combination and their antimicrobial properties. Molecules 17, 3989-4006. doi: 10.3390/molecules 17043989

Bennis, S., Chami, F., Chami, N., Bouchikhi, T., and Remmal, A. (2004). Surface alteration of Saccharomyces cerevisiae induced by thymol and eugenol. Lett. Appl. Microbiol. 38, 454-458. doi: 10.1111/j.1472-765X.2004. 01511.x

Betancourt, L., Phandanauvong, V., and Patiño, R. (2012). Composition and bactericidal activity against beneficial and pathogenic bacteria of oregano essential oils from four chemotypes of Origanum and Lippia genus. Arq. Bras. de Med. Veterinária e Zootecnia 59, 21-31.

Biasi-Garbin, R. P., Otaguiri, E. S., Morey, A. T., da Silva, M. F., Morguette, A. E. B., Lancheros, C. A. C., et al. (2015). Effect of eugenol against Streptococcus agalactiae and synergistic interaction with biologically produced silver nanoparticles. Evid. Based Complement. Altern. Med. 2015:861497. doi: $10.1155 / 2015 / 861497$

Bibbs, R. K., Harris, R. D., Peoples, V. A., Barnett, C., Singh, S. R., Dennis, V. A., et al. (2014). Silver polyvinyl pyrrolidone nanoparticles exhibit a capsular polysaccharide influenced bactericidal effect against Streptococcus pneumoniae. Front. Microbiol. 5:665. doi: 10.3389/fmicb.2014.00665

Bollenbach, T. (2015). Antimicrobial interactions: mechanisms and implications for drug discovery and resistance evolution. Curr. Opin. Microbiol. 27, 1-9. doi: 10.1016/j.mib.2015.05.008

Burt, S. (2004). Essential oils: their antibacterial properties and potential applications in foods - a review. Int. J. Food Microbiol. 94, 223-253. doi: 10.1016/j.ijfoodmicro.2004.03.022

Burt, S. A., and Reinders, R. D. (2003). Antibacterial activity of selected plant essential oils against Escherichia coli O157:H7. Lett. Appl. Microbiol. 36, 162-167. doi: 10.1046/j.1472-765X.2003.01285.x

Busatta, C., Mossi, A. J., Rodrigues, M. R. A., Cansian, R. L., and Oliveira, J. V. (2007). Evaluation of Origanum vulgare essential oil as antimicrobial agent in sausage. Braz. J. Microbiol. 38, 610-616. doi: 10.1590/S151783822007000400006

Bush, K. (2010). Bench-to-bedside review: the role of beta-lactamases in antibioticresistant Gram-negative infections. Critical Care. 14:224. doi: 10.1186/cc8892

Cacciatore, I., Di Giulio, M., Fornasari, E., Di Stefano, A., Cerasa, L. S., Marinelli, L., et al. (2015). Carvacrol Codrugs: a new approach in the antimicrobial plan. PLoS One 10:e0120937. doi: 10.1371/journal.pone. 0120937

Cantas, L., Shah, S. Q. A., Cavaco, L. M., Manaia, C. M., Walsh, F., Popowska, M., et al. (2013). A brief multi-disciplinary review on antimicrobial resistance in medicine and its linkage to the global environmental microbiota. Front. Microbiol. 4:96. doi: 10.3389/fmicb.2013.00096

Cardozo, V. F., Oliveira, A. G., Nishio, E. K., Perugini, M. R. E., Andrade, C. G. T. J., Silveira, W. D., et al. (2013). Antibacterial activity of extracellular compounds produced by a Pseudomonas strain against methicillin-resistant Staphylococcus aureus (MRSA) strains. Ann. Clin. Microbiol. Antimicrob. 12:12. doi: 10.1186/1476-0711-12-12
Cervato, G., Carabelli, M., Gervasio, S., Cittera, A., Cazzola, R., and Cestaro, B. (2000). Antioxidant properties of (Oregano vulgare) leaf extracts. J. Food Biochem. 24, 453-465. doi: 10.1111/j.1745-4514.2000.tb00715.x

Chin, N. X., Weitzman, I., and Della-Latta, P. (1997). In vitro activity of fluvastatin, a cholesterol-lowering agent, and synergy with flucanazole and itraconazole against candida species and Cryptococcus neoformans. Antimicrob. agents chemother. 41, 850-852.

Choi, J., Reipa, V., Hitchins, V. M., Goering, P. L., and Malinauskas, R. A. (2011). Physicochemical characterization and in vitro hemolysis evaluation of silver nanoparticles. Toxicol. Sci. 123, 133-143. doi: 10.1093/toxsci/kfr149

Cleff, M. B., Meinerz, A. R., Sallis, E. S., Antunes, T. A., Mattei, A., Rodrigues, M. R., et al. (2008). Toxicidade pré-clínica em doses repetidas do óleo essencial do Origanum vulgare L. (Orégano) em ratas Wistar. Latin Am. J. Pharm. 27, 704-709.

CLSI (2012). Methods for Dilution Antimicrobial Susceptibility Tests for Bacteria that Grow Aerobically. Available online at: http://antimicrobianos.com.ar/ATB/ wp-content/uploads/2012/11/03-CLSI-M07-A9-2012.pdf [Accessed October $17,2015]$.

de Lima, R., Seabra, A. B., and Durán, N. (2012). Silver nanoparticles: a brief review of cytotoxicity and genotoxicity of chemically and biogenically synthesized nanoparticles. J. Appl. Toxicol. 32, 867-879. doi: 10.1002/jat.2780

de Souza, E. L., Barros, J. C., Conceição, M. L., Gomes Neto, N. J., and Costa, A. C. V. (2009). Combined application of Origanum vulgare L. essential oil and acetic acid for controlling the growth of Staphylococcus aureus in foods. Braz. J. Microbiol. 40, 387-393. doi: 10.1590/S1517-83822009000200032

Devi, J. S., and Bhimba, B. V. (2012). Anticancer activity of silver nanoparticles synthesized by the seaweed Ulva lactuca in vitro. J. Nanomedine. Biotherapeutic Discov. 01:242. doi: 10.4172/scientificreports.242

Dhillon, R. H. P., and Clark, J. (2012). ESBLs: a clear and present danger? Crit. Care Res. Pract. 2012:625170. doi: 10.1155/2012/625170

Dibrov, P., Dzioba, J., Gosink, K. K., and Häse, C. C. (2002). Chemiosmotic mechanism of antimicrobial activity of $\mathrm{Ag}^{+}$in Vibrio cholerae. Antimicrob. Agents Chemother. 46, 8-11. doi: 10.1128/aac.46.8.2668-2670.2002

Dorman, H. J., and Deans, S. G. (2000). Antimicrobial agents from plants: antibacterial activity of plant volatile oils. J. Appl. Microbiol. 88, 308-316. doi: 10.1046/j.1365-2672.2000.00969.x

Drawz, S. M., and Bonomo, R. A. (2010). Three decades of $\beta$-lactamase inhibitors. Clin. Microbiol. Rev. 23, 160-201. doi: 10.1128/CMR.00037-09

Du, W. X., Olsen, C. W., Avena-Bustillos, R. J., McHugh, T. H., Levin, C. E., Mandrell, R., et al. (2009). Antibacterial effects of allspice, garlic, and oregano essential oils in tomato films determined by overlay and vapor-phase methods. J. Food Sci. 74, 390-397. doi: 10.1111/j.1750-3841.2009.01289.x

Durán, N., Alves, O. L., Esposito, E., de Souza, G. I., and Marcato, P. D. (2006). Processo de produção de nanopartículas de prata estabilizadas por proteinas na produção de produtos têxteis antibacterianos e o tratamento dos efluentes produzidos. Braz. patent PI 0605681-4 A. Campinas: BR. Instituto Nacional da Propriedade Industrial (INPI).

Durán, N., Marcato, P. D., Alves, O. L., Souza, G. I. H., and Esposito, E. (2005). Mechanistic aspects of biosynthesis of silver nanoparticles by several Fusarium oxysporum strains. J. Nanobiotechnology. 3:8. doi: 10.1186/1477-3155-3-8

Durán, N., Marcato, P. D., De Conti, R., Alves, O. L., Costa, F. T. M., and Brocchi, M. (2010). Potential use of silver nanoparticles on pathogenic bacteria, their toxicity and possible mechanisms of action. J. Braz. Chem. Soc. 21, 949-959. doi: 10.1590/S0103-50532010000600002

Durán, N., Marcato, P. D., Durán, M., Yadav, A., Gade, A., and Rai, M. (2011). Mechanistic aspects in the biogenic synthesis of extracellular metal nanoparticles by peptides, bacteria, fungi, and plants. Appl. Microbiol. Biotechnol. 90, 1609-1624. doi: 10.1007/s00253-011-3249-8

Fayaz, A. M., Balaji, K., Girilal, M., Yadav, R., Kalaichelvan, P. T., and Venketesan, R. (2010). Biogenic synthesis of silver nanoparticles and their synergistic effect with antibiotics: a study against Gram-positive and Gram-negative bacteria. Nanomed. Nanotechnol. Biol. Med. 6, 103-109. doi: 10.1016/j.nano.2009.04.006

Feng, Q., Wu, J., Chen, G. Q., Cui, F. Z., Kim, T. N., and Kim, J. O. (2000). A mechanistic study of the antibacterial effect of silver ions on Escherichia coli and Staphylococcus aureus. J. Biomed. Mater. Res. 52, 662-668. doi: 10.1002/10974636(20001215)52:4<662::AID-JBM10>3.0.CO;2-3

Fischbach, M. A. (2011). Combination therapies for combating antimicrobial resistance. Curr. Opin. Microbiol. 14, 519-523. doi: 10.1016/j.mib.2011.08.003 
Fontes, L. C., Neves, P. R., Oliveira, S., Silva, K. C., Hachich, E. M., Sato, M. I. Z., et al. (2011). Isolation of Pseudomonas aeruginosa coproducing metallo$\beta$-lactamase SPM-1 and 16S rRNA methylase RmtD1 in an urban river. Antimicrob. Agents Chemother. 55, 3063-3064. doi: 10.1128/AAC.00138-11

Gautam, N., Mantha, A. K., and Mittal, S. (2014). Essential oils and their constituents as anticancer agents: a mechanistic view. Biomed. Res. Int. 2014:154106. doi: 10.1155/2014/154106

Ghosh, I. N., Patil, S. D., Sharma, T. K., Srivastava, S. K., Pathania, R., and Navani, N. K. (2013). Synergistic action of cinnamaldehyde with silver nanoparticles against spore-forming bacteria: a case for judicious use of silver nanoparticles for antibacterial applications. Int. J. Nanomed. 8, 4721-4731. doi: 10.2147/IJN.S49649

Gilling, D. H., Kitajima, M., Torrey, J. R., and Bright, K. R. (2014). Antiviral efficacy and mechanisms of action of oregano essential oil and its primary component carvacrol against murine norovirus. J. Appl. Microbiol. 116, 1149-1163. doi: 10.1111/jam. 12453

Graves, J. L. Jr., Tajkarimi, M., Cunningham, Q., Campbell, A., Nonga, H., Harrison, S. H., et al. (2015). Rapid evolution of silver nanoparticle resistance in Escherichia coli. Front. Genet. 6:42. doi: 10.3389/fgene.2015.00042

Helander, I. M., Alakomi, H.-L., Latva-Kala, K., Mattila-Sandholm, T., Pol, I., Smid, E. J., et al. (1998). Characterization of the action of selected essential oil components on Gram-negative bacteria. J. Agric. Food Chem. 46, 3590-3595. doi: $10.1021 / \mathrm{j} f 980154 \mathrm{~m}$

Herman, A., and Herman, A. P. (2014). Nanoparticles as antimicrobial agents: their toxicity and mechanisms of action. J. Nanosci. Nanotechnol. 14, 946-957. doi: 10.1166/jnn.2014.9054

Hernández-Hernández, E., Regalado-González, C., Vázquez-Landaverde, P., Guerrero-Legarreta, I., and García-Almendárez, B. E. (2014). Microencapsulation, chemical characterization, and antimicrobial activity of mexican (Lippia graveolens H. B. K.) and european (Origanum vulgare L.) oregano essential oils. Sci. World J. 2014:641814. doi: 10.1155/2014/641814

Holt, K., and Bard, A. (2005). The interaction of silver (I) ions with the respiratory chain of Escherichia coli: an electrochemical and scanning electrochemical microscopy study of the antimicrobial mechanism of micromolar $\mathrm{Ag}^{+}$. Biochemistry 44, 13214-13223. doi: 10.1021/bi0508542

Honório, V. G., Bezerra, J., Souza, G. T., Carvalho, R. J. (2015). Inhibition of Staphylococcus aureus cocktail using the synergies of oregano and rosemary essential oils or carvacrol and 1,8-cineole. Front. Microbiol. 6:1223. doi: $10.3389 /$ fmicb. 2015.01223

Hyldgaard, M., Mygind, T., and Meyer, R. L. (2012). Essential oils in food preservation: mode of action, synergies, and interactions with food matrix components. Front. Microbiol. 3:12. doi: 10.3389/fmicb.2012.00012

Izumi, E., Ueda-Nakamura, T., Veiga, V. F. Jr., Pinto, A. C., and Nakamura, C. V. (2012). Terpenes from copaifera demonstrated in vitro antiparasitic and synergic activity. J. Med. Chem. 55, 2994-3001. doi: 10.1021/jm201451h

Jain, J., Arora, S., Rajwade, J. M., Omray, P., Khandelwal, S., and Paknikar, K. M. (2009). Silver nanoparticles in therapeutics: development of an antimicrobial gel formulation for topical use. Mol. Pharm. 6, 1388-1401. doi: $10.1021 / \mathrm{mp} 900056 \mathrm{~g}$

Kalemba, D., and Kunicka, A. (2003). Antibacterial and antifungal properties of essential oils. Curr. Med. Chem. 10, 813-829. doi: 10.2174/0929867033457719

Kim, S. H., Lee, H. S., Ryu, D. S., Choi, S. J., and Lee, D. S. (2011). Antibacterial activity of silver-nanoparticles against Staphylococcus aureus and Escherichia coli. J. Microbiol. Biotechnol. 39, 77-85.

Koga, V. L., Rodrigues, G. R., Scandorieiro, S., Vespero, E. C., Oba, A., and De Brito, B. G. (2015). Evaluation of the antibiotic resistance and virulence of Escherichia coli strains isolated from chicken carcasses in 2007 and 2013 from Paraná, Brazil. Foodborne Pathog. Dis. 12, 479-485. doi: 10.1089/fpd.2014.1888

Kong, K. F., Schneper, L., and Mathee, K. (2010). Beta-lactam antibiotics: from antibiosis to resistance and bacteriology. APMIS 118, 1-36. doi: 10.1111/j.16000463.2009.02563.x

Lambert, R. J. W., Skandamis, P. N., Coote, P. J., and Nychas, G. J. E. (2001). A study of the minimum inhibitory concentration and mode of action of oregano essential oil, thymol and carvacrol. J. Appl. Microbiol. 91, 453-462. doi: 10.1046/j.1365-2672.2001.01428.x

Li, P., Li, J., Wu, C., Wu, Q., and Li, J. (2005). Synergistic antibacterial effects of $\beta$-lactam antibiotic combined with silver nanoparticles. Nanotechnology 16 , 1912-1917. doi: 10.1088/0957-4484/16/9/082
Li, W. R., Xie, X. B., Shi, Q. S., Zeng, H. Y., Ou-Yang, Y. S., and Chen, Y. B. (2010). Antibacterial activity and mechanism of silver nanoparticles on Escherichia coli. Appl. Microbiol. Biotechnol. 85, 1115-1122. doi: 10.1007/s00253-009-2159-5

Lok, C. N., Ho, C. M., Chen, R., He, Q. Y., Yu, W. Y., Sun, H., et al. (2006). Proteomic analysis of the mode of antibacterial action of silver nanoparticles. J. Proteome Res. 5, 916-924. doi: 10.1021/pr0504079

Losasso, C., Belluco, S., Cibin, V., Zavagnin, P., Mičetić, I., Gallocchio, F., et al. (2014). Antibacterial activity of silver nanoparticles: sensitivity of different Salmonella serovars. Front. Microbiol. 5:227. doi: 10.3389/fmicb.2014. 00227

Mancini, E., Camele, I., Elshafie, H. S., De Martino, L., Pellegrino, C., Grulova, D., et al. (2014). Chemical composition and biological activity of the essential oil of Origanum vulgare ssp. hirtum from different areas in the Southern Apennines (Italy). Chem. Biodivers. 11, 639-651. doi: 10.1002/cbdv.201300326

Mandal, M. D., and Mandal, S. (2011). Honey: its medicinal property and antibacterial activity. Asian Pac. J. Trop. Biomed. 1, 154-160. doi: 10.1016/S2221-1691(11)60016-6

Medini, H., Elaissi, A., Farhat, F., Khouja, M. L., Chemli, R., and Harzallah-Skhiri, F. (2009). Seasonal and geographical influences on the chemical composition of Juniperus phoenicea L. essential oil leaves from the northern Tunisia. Chem. Biodivers. 6, 1378-1387. doi: 10.1002/cbdv.200800202

Mehdi, S. J., Ahmad, A., Irshad, M., Manzoor, N., and Rizvi, M. M. A. (2011). Cytotoxic effect of carvacrol on human cervical cancer cells. Biol. Med. 3, 307-312.

Naqvi, S. Z. H., Kiran, U., Ali, M. I., Jamal, A., Hameed, A., Ahmed, S., et al. (2013). Combined efficacy of biologically synthesized silver nanoparticles and different antibiotics against multidrug-resistant bacteria. Int. J. Nanomed. 8, 3187-3195. doi: $10.2147 /$ IJN.S49284

Nazzaro, F., Fratianni, F., De Martino, L., Coppola, R., and De Feo, V. (2013). Effect of essential oils on pathogenic bacteria. Pharmaceuticals 6, 1451-1474. doi: $10.3390 /$ ph6121451

NCCLS (1999). Methods for Determining Bactericidal Activity of Antimicrobial Agents. Available online at: http://shop.clsi.org/site/Sample_pdf/M26A_ sample.pdf [Accessed October 17, 2015].

Nostro, A., Blanco, A. R., Cannatelli, M. A., Enea, V., Flamini, G., Morelli, I., et al. (2004). Susceptibility of methicillin-resistant Staphylococci to oregano essential oil, carvacrol and thymol. FEMS Microbiol. Lett. 230, 191-195. doi: 10.1016/S0378-1097(03)00890-5

Nostro, A., Roccaro, A. S., Bisignano, G., Marino, A., Cannatelli, M. A., Pizzimenti, F. C., et al. (2007). Effects of oregano, carvacrol and thymol on Staphylococcus aureus and Staphylococcus epidermidis biofilms. J. Med. Microbiol. 56, 519-523. doi: 10.1099/jmm.0.46804-0

Nowack, B., Krug, H. F., and Height, M. (2011). 120 years of nanosilver history: implications for policy makers. Environ. Sci. Technol. 45, 1177-1183. doi: $10.1021 / \mathrm{es} 103316 \mathrm{q}$

Palanisamy, N. K., Ferina, N., Amirulhusni, A. N., Mohd-Zain, Z., Hussaini, J., Ping, L. J., et al. (2014). Antibiofilm properties of chemically synthesized silver nanoparticles found against Pseudomonas aeruginosa. J. Nanobiotechnol. 12:2. doi: 10.1186/1477-3155-12-2

Panacek, A., Kvítek, L., Prucek, R., Kolar, M., Vecerova, R., Pizurova, N., et al. (2006). Silver colloid nanoparticles: synthesis, characterization and their antibacterial activity. J. Phys. Chem. B. 110, 16248-16253. doi: $10.1021 / j p 063826 \mathrm{~h}$

Patel, G., and Bonomo, R. A. (2013). "Stormy waters ahead": global emergence of carbapenemases. Front. Microbiol. 4:48. doi: 10.3389/fmicb.2013.00048

Pitout, J. D. D. (2012). Extraintestinal pathogenic Escherichia coli: a combination of virulence with antibiotic resistance. Front. Microbiol. 3:9. doi: 10.3389/fmicb.2012.00009

Prado, T., Pereira, W. C., Silva, D. M., Seki, L. M., Carvalho, A. P. D. A., and Asensi, M. D. (2007). Detection of extended-spectrum $\beta$-lactamase-producing Klebsiella pneumoniae in effluents and sludge of a hospital sewage treatment plant. Lett. Appl. Microbiol. 46, 136-141. doi: 10.1111/j.1472-765x.2007.0 2275. $\mathrm{x}$

Queenan, A. M., and Bush, K. (2007). Carbapenemases: the versatile $\beta$-lactamases. Clin. Microbiol. Rev. 20, 440-458. doi: 10.1128/CMR.00001-07

Rai, M. K., Deshmukh, S. D., Ingle, A. P., and Gade, A. K. (2012). Silver nanoparticles: the powerful nanoweapon against multidrug-resistant bacteria. J. Appl. Microbiol. 112, 841-852. doi: 10.1111/j.1365-2672.2012.05253.x 
Rhayour, K., Bouchikhi, T., Tantaoui-Elaraki, A., Sendide, K., and Remmal, A. (2003). The mechanism of bactericidal action of oregano and clove essential oils and of their phenolic major components on Escherichia coli and Bacillus subtilis. J. Essent. Oil Res. 15, 286-292. doi: 10.1080/10412905.2003.9712144

Rice, L. B. (2012). Mechanisms of resistance and clinical relevance of resistance to $\beta$-lactams, glycopeptides, and fluoroquinolones. Mayo Clin. Proc. 87, 198-208. doi: 10.1016/j.mayocp.2011.12.003

Rosato, A., Piarulli, M., Corbo, F., Muraglia, M., Carone, A., Vitali, M. E., et al. (2010). In vitro synergistic antibacterial action of certain combinations of gentamicin and essential oils. Curr. Med. Chem. 17, 3289-3295. doi: $10.2174 / 092986710792231996$

Rosato, A., Vitali, C., De Laurentis, N., Armenise, D., and Milillo, M. A. (2007). Antibacterial effect of some essential oils administered alone or in combination with norfloxacin. Phytomedicine 14, 727-732. doi: 10.1016/j.phymed.2007.01.005

Rubin, J. E., Ekanayake, S., and Fernando, C. (2014). Carbapenemase-producing Organism in Food, 2014. Emerg. Infect. Dis. 20, 1264-1265. doi: 10.3201/ eid2007.140534

Sankar, R., Karthik, A., Prabu, A., Karthik, S., Shivashangari, K. S., and Ravikumar, V. (2013). imediated biosynthesis of silver nanoparticles for its antibacterial and anticancer activity. Colloids Surf. B Biointerfaces 108, 80-84. doi: 10.1016/j.colsurfb.2013.02.033

Sastry, M., Ahmad, A., Islam Khan, M., and Kumar, R. (2003). Biosynthesis of metal nanoparticles using fungi and actinomycete. Curr. Sci. 85, 162-170.

Shaikh, S., Fatima, J., Shakil, S., Rizvi, S. M. D., and Kamal, M. A. (2015). Antibiotic resistance and extended spectrum beta-lactamases: types, epidemiology and treatment. Saudi J. Biol. Sci. 22, 90-101. doi: 10.1016/j.sjbs.2014.08.002

Si, H., Hu, J., Liu, Z., and Zeng, Z. L. (2008). Antibacterial effect of oregano essential oil alone and in combination with antibiotics against extended-spectrum $\beta$ lactamase-producing Escherichia coli. FEMS Immunol. Med. Microbiol. 53, 190-194. doi: 10.1111/j.1574-695X.2008.00414.x

Silva, K. C., and Lincopan, N. (2012). Epidemiologia das betalactamases de espectro estendido no Brasil : impacto clínico e implicações para o agronegócio. J. Bras. Patol. Med. Lab. 48, 91-99. doi: 10.1590/S1676-24442012000200004

Singh, K., Panghal, M., Kadyan, S., Chaudhary, U., and Yadav, J. (2014). Green silver nanoparticles of Phyllanthus amarus: as an antibacterial agent against multi drug resistant clinical isolates of Pseudomonas aeruginosa. J. Nanobiotechnol. 12:40. doi: 10.1186/s12951-014-0040-x

Smith-Palmer, A., Stewart, J., and Fyfe, L. (1998). Antimicrobial properties of plant essential oils and essences against five important food-borne pathogens. Lett. Appl. Microbiol. 26, 118-122. doi: 10.1046/j.1472-765X.1998.00303.x

Sobral, M. V., Xavier, A. L., Lima, T. C., and de Sousa, D. P. (2014). Antitumor activity of monoterpenes found in essential oils. Sci. World J. 2014:953451. doi: $10.1155 / 2014 / 953451$

Souza, E. L., Barros, J. C., Oliveira, C. E. V., and Conceição, M. L. (2010). Influence of Origanum vulgare L. essential oil on enterotoxin production, membrane permeability and surface characteristics of Staphylococcus aureus. Int. J. Food Microbiol. 137, 308-311. doi: 10.1016/j.ijfoodmicro.2009.11.025
Souza, E. L., Oliveira, C. E. V., Stamford, T. L. M., Conceição, M. L., and Gomes Neto, N. J. (2013). Influence of carvacrol and thymol on the physiological attributes, enterotoxin production and surface characteristics of Staphylococcus aureus strains isolated from foods. Braz. J. Microbiol. 44, 29-35. doi: 10.1590/S1517-83822013005000001

Stojković, D., Glamočlija, J., Ćirić, A., Nikolić, M., Ristić, M., and Šiljegović, J. (2013). Investigation on antibacterial synergism of Origanum vulgare and Thymus vulgaris essential oils. Arch. Biol. Sci. 65, 639-644. doi: 10.2298/ABS1302639S

Subashini, J., Khanna, V. G., and Kannabiran, K. (2014). Anti-ESBL activity of silver nanoparticles biosynthesized using soil Streptomyces species. Bioprocess Biosyst. Eng. 37, 999-1006. doi: 10.1007/s00449-0131070-8

Suzuki, É. Y., Soldati, P. P., Chaves, M. G. A. M., and Nádia, R. B. (2015). Essential oil from Origanum vulgare Linnaeus: an alternative against microorganisms responsible for bad perspiration odor. J. Young Pharm. 7, 12-20. doi: 10.5530/jyp.2015.1.4

Szabó, M. Á., Varga, G. Z., Hohmann, J., Schelz, Z., Szegedi, E., Amaral, L., et al. (2010). Inhibition of quorum-sensing signals by essential oils. Phytother. Res. 24, 782-786. doi: 10.1002/ptr.3010

Theophel, K., Schacht, V. J., Schlüter, M., Schnell, S., Stingu, C. S., Schaumann, R., et al. (2014). The importance of growth kinetic analysis in determining bacterial susceptibility against antibiotics and silver nanoparticles. Front. Microbiol. 5:544. doi: 10.3389/fmicb.2014.00544

Traub, W. H., and Kleber, I. (1975). In vitro additive effect of polymyxin B and rifampin against Serratia marcescens. Antimicrob. Agents Chemother. 7, 874-876. doi: 10.1128/AAC.7.6.874

Turlej, A., Hryniewicz, W., and Empel, J. (2011). Staphylococcal Cassette Chromosome mec (SCCmec) classification and typing methods: an overview. Pol. J. Microbiol. 60, 95-103.

Ultee, A., Kets, E. P. W., and Smid, E. J. (1999). Mechanisms of action of carvacrol on the food-borne pathogen. Appl. Environ. Microbiol. 65 , 4606-4610.

Yeh, P. J., Hegreness, M. J., Aiden, A. P., and Kishony, R. (2009). Drug interactions and the evolution of antibiotic resistance. Nat. Rev. Microbiol. 7, 460-466. doi: $10.1038 /$ nrmicro2133

Conflict of Interest Statement: The authors declare that the research was conducted in the absence of any commercial or financial relationships that could be construed as a potential conflict of interest.

Copyright (c) 2016 Scandorieiro, Camargo, Contreras, Yamada-Ogatta, Nakamura, Oliveira, Andrade, Duran, Nakazato and Kobayashi. This is an open-access article distributed under the terms of the Creative Commons Attribution License (CC BY). The use, distribution or reproduction in other forums is permitted, provided the original author(s) or licensor are credited and that the original publication in this journal is cited, in accordance with accepted academic practice. No use, distribution or reproduction is permitted which does not comply with these terms. 